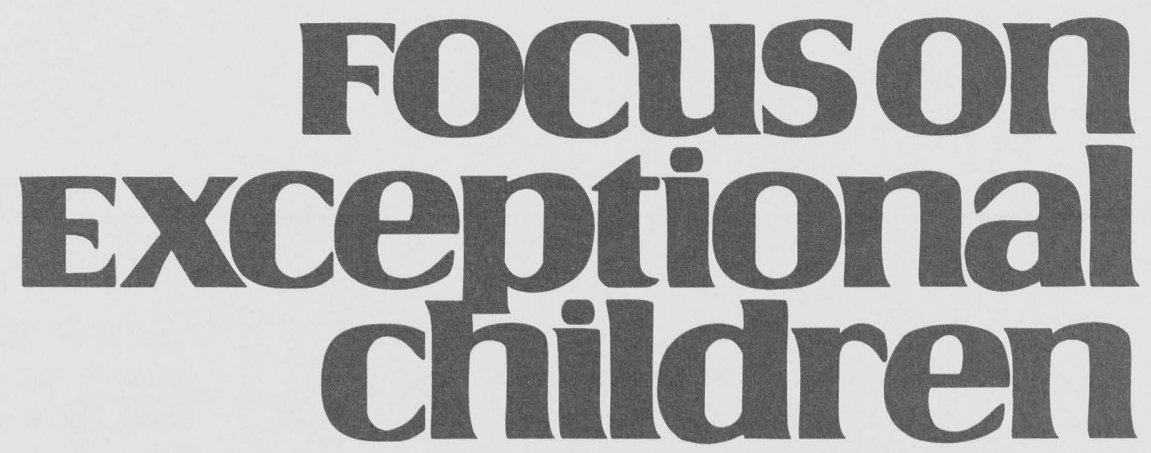

\title{
Peer-Mediated Instruction and Interventions
}

\section{Cheryl A. Utley, Susan L. Mortweet, and Charles R. Greenwood}

Twenty years of research (1976-1996) investigating the inclusion of students with disabilities have consistently supported the finding that simply placing these students in general education classrooms without instructional supports for academic and social learning generally does not result in measurable academic and social benefits (Goodlad \& Lovitt, 1993; Heller, Holtzman, \& Messick, 1982; Stainback \& Stainback, 1996; Ysseldyke, Algozzine, \& Thurlow, 1992). For children with disabilities to be successful in inclusive settings, researchers have proposed that the development of academic skills and social competence, particularly with peers, become a major focus of school-based programs (Greenwood, Terry, Delquadri, Elliott, \& Arreaga-Mayer, 1995). An inclusionary model of education must incorporate an analysis of effective teaching procedures and practices-what has to be done during instruction to produce optimal growth in students' learning. Classroom interventions must be available to teach appropriate academic and social behaviors and interactions among normally achieving students and students with disabilities.

In recent years the knowledge base and research studies supporting peer-mediated approaches to instruction have increased substantially. A rich knowledge base supports peermediated instruction and interventions (PMII) to facilitate learning in heterogeneous groups of students with varying abilities, interests, and backgrounds. Numerous research studies have demonstrated that effective instructional processes - engaged time, time management, success rate, academic learning time, monitoring, structuring, and questioning - can be incorporated into PMII with important benefits (Greenwood, Carta, \& Kamps, 1990). Further, the results of studies have consistently been positive and indicate peers can be trained, through specific PMII instructional procedures, to follow directions that lead to increased student outcomes.

Because PMII has major implications for the instruction of children with disabilities integrated in general education classrooms, we discuss PMII from two major perspectives:

1. We review the components of PMII that enlist sources of peer influence in support of instructional goals. ${ }^{1}$ We define PMII as a viable instructional alternative in which

\footnotetext{
${ }^{1}$ Empirical studies in this review were located through many sources. A computer-assisted search of the ERIC and PSYCLIT databases was conducted for the years 1970-1995. Reference lists from articles also were examined for additional studies and relevant journals. Based on the importance of identifying effective peer-mediated instruction and interventions for students with disabilities, the following criteria for determining the inclusion or exclusion of empirical studies were established: participants between ages 5 and 19 years who were described as learning disabled (LD), educable mentally retarded (EMR), behaviorally disordered (BD), autistic, and severely disabled; data-based experimental or quasi-experimental evaluation of specific peer-mediated interventions; and quantitative measurement of academic (e.g., percent correct, accuracy, fluency) and social variables (e.g., disruptiveness, social skill, social interaction, social acceptance).
}

The authors are all affiliated with the Juniper Gardens Children's Project, University of Kansas, Kansas City. 
peers are used as instructional agents or helpers in orchestrating students' learning. Greenwood, Terry, Delquadri, Elliott, and Arreaga-Mayer (1995) stated that PMII is an increasingly sophisticated instructional technology consisting of "a set of practices and strategies that may be used to create the instructional processes known to be necessary to optimizing students' performance on standardized achievement tests" (p. 23). These strategies range from incidental peer help, supervision, and support for direct instruction in a subject matter (Greenwood, Carta, \& Hall, 1988; Kalfus, 1984). In PMII, the teacher's role changes from delivering instruction to establishing monitoring and improving peer-teaching activities.

2. We describe instructional systems that incorporate PMII components with other elements of effective instruction and discuss recent findings supporting their effectiveness.

3. We discuss implications for research and practice.

When studies have compared peer-mediated versus conventional teacher-mediated procedures (Greenwood, Delquadri, \&

\section{Focuson
Exceptional children}

ISSN 0015-511X

FOCUS ON EXCEPTIONAL CHILDREN (USPS 203-360) is published monthly except June, July, and August as a service to teachers, special educators, curriculum specialists, administrators, and those concerned with the special education of exceptional children. This publication is annotated and indexed by the ERIC Clearinghouse on Handicapped and Gifted Children for publication in the monthly Current Index to Journals in Education (CIJE) and the quarterly index, Exceptional Children Education Resources (ECER). The full text of Focus on Exceptional Children is also available in the electronic versions of the Education Index. It is also available in microfilm from Xerox University Microfilms, Ann Arbor, MI. Subscription rates: Individual, \$30 per year; institutions, $\$ 40$ per year. Copyright (C) 1997, Love Publishing Company. All rights reserved. Reproduction in whole or part without written permission is prohibited. Printed in the United States of America. Periodicals postage is paid at Denver, Colorado. POSTMASTER: Send address changes to:

$$
\begin{gathered}
\text { Love Publishing Company } \\
\text { Executive and Editorial Office } \\
\text { P.O. Box } 22353 \\
\text { Denver, Colorado } 80222 \\
\text { Telephone (303) } 757-2579
\end{gathered}
$$

Edward L. Meyen

University of Kansas
Glenn A. Vergason Georgia State University

Richard J. Whelan

University of Kansas Medical Center

Stanley F. Love

Publisher
Kristin Kennedy

Assistant Editor
Hall, 1989; Fantuzzo, Davis, \& Ginsburg, 1995), results have demonstrated the relative effectiveness of PMII on instructional processes and student achievement. As illustrated in Table 1, PMII can offer a number of advantages, compared to conventional teacher-mediated instruction, in facilitating and creating processes known to result in academic outcomes. At the most basic level, the advantage of peer-mediated methods is the creation of more favorable pupil-teacher ratios so the goals of individualization, response supervision, error correction, and reinforcement are more likely to be achieved.

Compared to traditional forms of teacher-mediated instruction, research has confirmed that PMII increases time on academic tasks with behaviors such as writing spelling words, solving mathematical equations, oral reading, and task completion reliably produced by peer-tutoring programs. Another advantage is that PMII provides more opportunities to respond, in which students with and without disabilities can use teacherstudent discussions, worksheets, workbooks or other written tasks, computer tasks, or structured projects, and peer interactions as contexts for using academic and social knowledge. In addition to increased opportunities to respond, PMII employs procedures that lead to (a) frequent error identification, (b) the practicing of correct responses, (c) immediate feedback and correction to increase rates of learning, and (d) help and encouragement from peers (Greenwood, Carta, Walker, ArreagaMayer, \& Dinwiddie, Carta, \& Kamps, 1990).

Other advantages of PMII include tapping the positive side of peer-group influence and providing powerful contexts for students to work together in cooperative and competitive learning situations to achieve common goals such as completing work tasks and earning points. Finally, when peer-mediated procedures are employed, students are able to motivate their peers to contribute their best performance to completing tasks and ensuring success (Greenwood, Terry, Delquadri, et al., 1995).

\section{COMPONENTS OF PMII}

Studies of peer influences and peer relations among children can be categorized as (a) naturalistic-observation studies, (b) manipulations of peer situations, the classroom context, and environment, and (c) peers as behavior-change agents (Field, 1984). In research conducted with young children with and without disabilities in general and special education classrooms, peer-related behaviors modeled by the typical students are accompanied by increases in the frequency of those behaviors by the students with disabilities. In studying various preschool classroom environments and the nature of peer and teacher interactions, researchers have found that (a) peer interactions are more frequent in classrooms featuring lower teacher-child ratios, (b) fewer teacher directives and free-play- 


\section{TABLE 1 \\ Active PMII Components}

\section{Component}

1. Peer modeling

2. Peer initiation training

3. Peer monitoring

4. Peer networking

5. Peer tutoring

6. Group-oriented contingencies
What They Do and How They Work

\author{
Exemplars and imitation of appropriate, competent \\ behavior \\ Opportunities to respond \\ Evaluation/feedback on responding \\ Peer support extended across time and settings \\ One-on-one instruction \\ An individual's rewards are based in whole or in part \\ on the successful performance of self and others
}

oriented curricula contribute to more frequent peer interactions, and (c) less complex toys and equipment that are larger and less portable seem to facilitate peer interactions. Effective strategies that utilize peers as behavior-change agents are modeling or peer imitations, social reinforcement, and tutoring.

Researchers and practitioners have recognized the effectiveness of peer influences in improving classroom and academic performance. These influences, also referred to as components of PMII, consist of (a) peer modeling, (b) peer initiation training, (c) peer monitoring, (d) peer networking, (e) peer tutoring, and (f) group-oriented contingencies (see Table 2). These components are based on principles derived from applied behavior analysis (Greenwood \& Hops, 1981), mastery learning (Keller, 1968), social learning theory (Bandura, 1968; Wagner, 1990), and process-products studies of effective instruction (Brophy, 1979). They are active ingredients of PMII and support specific teaching practices that create classroom processes that, in turn, lead to accelerated gains in students' performance on measures of achievement or social competence in general and special education classrooms. These components as shown by past research powerfully affect whether learning has or has not occurred.

\section{Peer Modeling}

Peer modeling encompasses a variety of instructional techniques that rely on the physical arrangement of an environment to include a child demonstrating appropriate behavior for a less skilled child to imitate (Strain, 1981). For example, in peerproximity or peer-pairing interventions, a socially competent, untrained peer is paired with a child who is less competent to increase the opportunity for direct interaction (Odom \& Strain, 1984). This approach has been investigated with withdrawn preschoolers (Furman, Rahe, \& Hartup, 1979), students with autism (McHale, 1983), students with behavioral disorders (BD) (Mathur \& Rutherford, 1991), and students with educa- ble mental retardation (EMR) (Rucker \& Vincenzo, 1970), with some success in increasing social interactions. Overall, however, improvements in the social behavior of the less competent child are not demonstrated, or the maintenance of positive results are not addressed or reported (Devoney, Guralnick, \& Rubin, 1974; Guralnick, 1976; Odom \& Strain, 1984; Rucker \& Vincenzo, 1970; Strain \& Odom, 1986).

Another peer modeling intervention is to have socially withdrawn or isolated children watch a film in which peer models demonstrate appropriate social behavior. Filmed interventions generally have been effective at increasing social interactions, particularly when an adult is commenting on the appropriate behavior being modeled in the film (O'Conner, 1972). Other researchers have added to the film a "coping" character who is talking about his or her own social situations as they are occurring. Results of these studies suggest that having a peer model narrate the various social scenarios in first-person is more effective at improving social behavior and increasing social interactions than having a third-person, child narrate the film (Jakibchuck \& Smeriglio, 1976). Filmed peer-modeling interventions may not be as useful for students with severe disabilities such as autism, who may not attend effectively to the salient social behavior the model in the film is trying to portray (Strain, 1981).

More recently and more typically, peer-modeling interventions are conducted "live" and are used in combination with other strategies (e.g., social skills training) (Elliott \& Gresham, 1993; Hollin \& Trower, 1988). For example, young children with mental retardation (MR) increased their appropriate social behavior after watching a typical peer modeling play behavior and being prompted and reinforced for imitating the behavior (Apolloni, Cooke, \& Cooke, 1977). Positive results, including increased social skills and decreased inappropriate behavior, also have been reported for preschoolers with developmental delays who watched peer models demonstrate appropriate social behavior along with exposure to role-playing, direct instruction, and adult reinforcement (Matson, Fee, Coe, \& Smith, 1991). 
Advantages and Disadvantages of Peer- and Teacher-Mediated Instructional Approaches

\begin{tabular}{lll}
\hline & & Mediator \\
\cline { 2 - 3 } Teacher Factor & Teacher & Peer \\
\hline Pupil/teacher ratio & Advantages & \\
Engaged time & High & Low \\
Opportunities to respond & Variable & High \\
Opportunities for error correction & Low & High \\
Immediacy of error correction & Low & High \\
Opportunities for help and correction & Delayed & Immediate \\
Opportunities for both competitive and & Few & Many \\
cooperative learning experiences & Few & Many \\
Motivation & & \\
& Teacher support & Peer plus teacher support \\
\hline Peer training requirements & Disadvantages & \\
Quality control requirements & Few & Many \\
Content coverage & Few & Many \\
Peer selection & Good & Variable \\
Curriculum adaptations & Not required & Required \\
Costs & Few & Many \\
Ethical concerns & High & Low
\end{tabular}

Source: "Teacher-mediated Versus Peer-Mediated Instruction: A Review of Educational Advantages and Disadvantages,” by C. R. Greenwood, J. J. Carta, \& D. Kamps, in H. C. Foot, M. J. Morgan, \& R. H. Shute (Eds.), Children Helping Children (pp. 177-205) (New York: John Wiley \& Sons Ltd, 1990).

Peer modeling is an important component in many peermediated strategies, including peer-initiation training, peer tutoring, and cooperative learning, regardless of whether modeling is or is not reported as a specific strategy in the intervention. One premise of many peer-mediated interventions is that having a peer available to model appropriate behaviors to a less skilled child increases the likelihood of observational learning because of perceived similarity with the peer model (Kornhaber $\&$ Schroeder, 1975). Despite the potential effectiveness of peer modeling as a teaching strategy, simply placing students together without incorporating other intervention procedures most likely will not result in significant changes in the less skilled child's behavior (Guralnick, 1976; Odom \& Strain, 1986; Vaughn \& Lancelotta, 1990). This point is especially important to remember when considering the success of integrating a student with disabilities into a general education classroom, where instructional strategies for both academic and social behaviors are necessary to facilitate successful inclusion (Cullinan, Sabornie, \& Crossland, 1992; Siperstein, 1992).

\section{Peer Initiation Training}

One of the most well researched and frequently used peermediated strategies to improve social behavior for children with disabilities is peer-initiation training (Strain \& Odom, 1986). Typically, peer initiation training requires a teacher to train peers how to evoke and maintain desired social and communicative behaviors from a target child (Antia, 1994; McEvoy, Odom, \& McConnell, 1992; Odom \& Strain, 1984). Some common behaviors that peers are taught to use to facilitate social behavior and interactions are (a) establishing eye contact, (b) suggesting play activities, (c) initiating conversation, (d) offering or asking for help, (e) describing ongoing social interactions, (f) expanding the content of the target student's speech, and (g) demonstrating affection (Goldstein \& Wickstrom, 1986; Odom, Strain, Karger, \& Smith, 1986; Storey, Smith, \& Strain, 1993).

Peer-initiation training has successfully been used to increase the appropriate social behavior and interactions of preschoolers who were withdrawn (Day, Powell, \& Dy-Lin, 1982; Fantuzzo et al., 1988; Hecimovic, Fox, Shores, \& Strain, 1985), preschoolers with autism (Odom, Hoyson, Jamieson, \& 
Strain, 1985; Odom \& Strain, 1986; Shafer, Egel, \& Neef, 1984), and with school-aged children with autism (Brady et al., 1984; Handlan \& Bloom, 1993; Strain, Kerr, \& Ragland, 1979). For example, typical preschool peers were trained by teachers using role-play, prompting, and reinforcement to initiate social activities during freeplay with their peers who were withdrawn (Day et al., 1982). The results of these studies indicated an increase in typical peer social initiations and social interactions, including an increase in positive initiations by target students to trained typical peers (Strain, Shores, \& Timm, 1977). Similar positive social outcomes have been reported for peer initiation training with students with autism (Strain et al., 1979).

Some evidence of generalization has been reported for social initiations by typical peers to nontarget children in the classroom and for social interactions in nontrained settings (Strain, Shores, \& Timm, 1977). Peer initiation training with children who have more severe disabilities has been less successful in generalizing and maintaining social outcomes (Odom et al., 1985; Shafer et al., 1984). As with many social interventions, the generalization of social behaviors and interactions achieved with peer initiation training to other nontrained settings may not be obtained readily without additional programmed intervention (Mathur \& Rutherford, 1991; McEvoy et al., 1992). In general, peer initiation training has been effective in facilitating social initiations and responses between children with disabilities and their typical peers, with less evidence reported for the maintenance and generalization of social outcomes.

Although peer initiation training is considered a peer-mediated instructional strategy, the level of teacher involvement can be intensive and necessary for success of the intervention (Antia, 1994; McEvoy et al., 1992). Peers may be trained in sessions separate from the planned curriculum (Day et al., 1982), teachers may be present during the initial social play situation to prompt and reinforce typical peers for displaying trained behaviors (Handlan \& Bloom, 1993), or teachers may prompt and reinforce typical peers during the entire interaction (Goldstein \& Ferrell, 1987). Shafer et al. (1984) reported a successful reduction in the level of teacher involvement needed to facilitate interactions between preschoolers with autism and their typical peers by including the students with autism in the training.

Despite some evidence that teacher involvement can be reduced, the level of teacher intervention necessary to ensure successful social outcomes still must be determined. In conclusion, although more research must be conducted to determine ways to increase maintenance and generalization of social outcomes and to decrease teacher involvement, peer initiation training may be considered a generally effective peer-mediated strategy for increasing the social behaviors and interactions of children with and without disabilities.

\section{Peer Monitoring}

One of the most important goals for special education and early childhood education is to teach children with and without disabilities how to cope with their environment, perform a wide variety of self-care tasks, and participate in social and preacademic activities (Sainato, 1990; Goetz, Ayala, Hatfield, Marshall, \& Etzel, 1983). Completing these goals and tasks is problematic for children with disabilities. They may not have opportunities to practice (a) coping independently with the environment, (b) performing tasks without assistance from the teacher, and (c) performing activities without an enormous amount of teacher attention. In addition, individualized instruction may not allow children with disabilities to function independent of teacher monitoring and management.

One promising solution to teaching children with disabilities to function independently during the transition between classroom activities is peer-mediated intervention, the strategy by which children's behavior can be altered (Sainato, 1990). In an earlier study, Sainato, Strain, Lefebvre, \& Rapp (1987) used a peer-monitoring system in which socially competent preschoolers acted as buddies for their peers who had autism. Preschoolers assisted their friends to make different transitions around the classroom. Prior to implementing the buddy system, the teacher modeled the desired behavior. Following the training session, the typical children were able to help their buddies make quicker transitions with less disruptive behavior across three different transition activities (circle to table, snack to bathroom, circle to language). Teachers considered the peermonitoring strategy easy to implement because the buddy system promoted more social exchanges.

A series of earlier studies conducted by Carden-Smith and Fowler (1984) and Fowler (1986) showed that peer monitoring procedures (e.g., token systems) decreased disruptive behaviors during transition activities. Kindergarten children were assigned as team captains and distributed points for appropriate behavior to team members and to themselves on report cards depicting pictures of transition activities. Through role-playing activities, peers were trained to make point awards, prompt appropriate behavior, and provide corrective feedback based upon the children's behavior during transition time. Children were reinforced by participating in daily outdoor activities. Following the peer monitoring procedure, a self-monitoring procedure was implemented. Peer monitors were able to successfully initiate the token system without training by an adult to reduce disruptive behavior on the part of monitored peers. In addition, peers appointed as monitors continued that role throughout the day. Results also indicated that both the peermonitored and the self-monitored interventions reduced inappropriate behaviors during transition time. 
In one final study, Kohler, Schwartz, Cross, and Fowler (1989) implemented a peer-mediated strategy in a fifth-grade classroom during an independent work math period. Three students, identified as low-achieving, were selected as peer monitors for three students who engaged in high rates of off-task behavior such as looking around, and making paper airplanes during math class. The monitor training sessions consisted of rehearsing the roles of the monitor and point earner, and completing checklists that assessed on-task behavior, accuracy, neatness, and work completion. Peer monitors also were taught how to give verbal feedback to their partner about the quality of their work. The results indicated that (a) the peer-mediated intervention increased the appropriate study behaviors of the fifth-grade students during math class; and (b) the peer monitors and point earners produced comparable changes in their own appropriate behavior.

The major advantage of using peers as monitors was that the disciplinary and supervisory responsibilities of teachers were minimized. The benefits for children were twofold: (a) children who were peer monitors were placed in leadership roles; and (b) their participation in activities provided them opportunities to learn to make discriminations between appropriate and inappropriate behavior during transition times of the classroom.

\section{Applicability to Students with Mild Disabilities}

Researchers have demonstrated the efficacy of self-management and peer monitoring procedures with elementary-aged students with behavior problems (Nelson, Smith, \& Colvin, 1995), students with mild disabilities (McCurdy \& Shapiro, 1992; Rhode, Morgan, \& Young, 1983), and junior high school aged students with mild disabilities (Smith, Young, West, Morgan, \& Rhode, 1988). More recently, research has been conducted to determine the efficacy of self-management/selfmonitoring procedures with high school-aged students with mild disabilities (Hogan \& Prater, 1993; Smith, Nelson, Young \& West, 1992).

For example, a study conducted by Smith et al. (1992) compared teachers and peers as facilitators in the self-evaluation/management process and maintenance of behavioral gains in eight high school adolescents with learning disabilities (LD) during English classes. Eight typical peers enrolled in general education English classes served as peer facilitators. The criteria for selecting students with LD in general and special education classrooms included teacher reports of (a) off-task behaviors relative to peers during independent seatwork (e.g., failing to use academic materials appropriately, out of seat without permission, inattention to assigned tasks, talking to other students, swearing, and/or making inappropriate noises), and (b) inconsistent completion of assignments (e.g., independent seatwork, reading and answering chapter questions, dictionary work and grammar worksheets) relative to typical peers. A multiple baseline across experimental settings design was used to determine the effects of the self-management procedures on target behaviors and the generality of treatment effects across settings.

In summary, self-management procedures (self-recording, self-evaluation, self-reinforcement, self-instruction, and goal setting) with students with mild disabilities improved their academic and social behaviors in both general and special education classrooms. According to Nelson et al. (1995), researchers have incorporated several strategies to maximize the potential effectiveness of self-management procedures. Some of these are: (a) teaching students self-observation, self-recording, and self-evaluation procedures; (b) requiring students to make judgments about their behavior relative to an adult; (c) establishing contingencies for desirable behaviors; and (d) withdrawing procedures when students are controlling their own behavior reliably. In addition, peer-mediated self-management procedures are well suited for facilitating academic and behavior improvements across ages and disability groups and the generalization of these behaviors from special education to general education classrooms.

\section{Peer Network Strategies}

The literature is replete with interventions (e.g., peer-mediated) designed to increase the social competence and language development of students with autism. Inclusionary programs for students with autism have focused on interventions that increase their social-communicative behaviors and language development (Kamps, Barbetta, Leonard, Dugan, \& Delquadri, 1992; McEvoy \& Odom, 1987; Ostrosky \& Kaiser, 1995; Strain \& Odom, 1986). In utilizing peer-mediated strategies, peers are instructional resources in which an adult trains a typical peer to interact effectively with students with autism. Following the training, student dyads are arranged for social activities and trained peers are instructed to prompt and encourage social responses from students with autism, as well as model and reinforce appropriate social behaviors (Farmer \& Cairns, 1991; Goldstein, Kaczmarek, Pennington, \& Shafer, 1992; Haring \& Breen, 1992; Horner, Meyer, \& Fredericks, 1987; Sasso, Garrison-Harrell, \& Rogers, 1994). Procedural components include removing the adult from the intervention and using peers to engage in ongoing, age-appropriate interactions in natural social contexts.

Peer networks related to peer initiation interventions are defined as groups of individuals who demonstrate an interest in understanding the individual with disabilities and having an impact on that person's life (Chadsey-Rusch, 1986). The primary goal of peer network intervention is to promote a positive social environment for students with autism by creating a support system of friends and socially competent peers. 
A limited number of studies have been published in support of peer networks. In studying the efficacy of peer networks with students with disabilities, Haring and Breen (1992) introduced a peer network within a peer clique during lunchtime activities. The criteria for selecting peers were that (a) both groups of students have classes together and know each other informally; and (b) that they share common interests, hobbies, and on-campus jobs. In the initial phase of the study, typical students were recruited to form four or five peer networks and discuss ways to include students with disabilities in the social activities within the school environment. Network peers outlined their schedules, chose specific times to interact socially with students with autism and other disabilities in school, and participated in out-of-school social events. Network peers were successfully taught strategies that mediate, reinforce, and maintain positive social interactions and responses. The frequency and quality of the social interactions were increased positively between the network peers and students with autism and disabilities.

More recently, Garrison-Harrell (1996) studied the social competence and social language of three elementary-aged children with autism. Appropriate social communication skills were taught via an augmentative communication system, and peer networks were formed during school-based activities that included language arts, reading, computer skills, lunch, and recess. Network peers were taught to interact socially during structured and unstructured activities and to use a variety of visual prompting systems (e.g., augmentative communication system, topic cards, and language strips) to increase the socialcommunicative behaviors of students with autism.

Peer network activities included training in the student's augmentative communication system and social interaction skills instruction (e.g., initiation of conversations, response to conversations, saying something nice, sharing, giving instructions, sharing ideas, and maintaining conversations). Positive findings were found suggesting that peer-mediated procedures and peer network strategies (a) facilitate communicative strategies and social and communication skills of students with autism, and (b) enhance and encourage friendships between students with autism and their typical peers.

\section{Peer Tutoring Approaches}

Peer tutoring, according to Foot, Shute, Morgan, and Barron (1990), represents an "unusual kind of social relationship in which children of relatively equal standing are given formal roles (by adults) in which their status is differentiated, possibly artificially or arbitrarily, for the purposes of promoting academic achievement and social competence" (p. 65). In the research-to-practice literature, peer tutoring represents a class of practices and strategies that employ peers as one-onone teachers to provide individualized instruction, practice, repetition, and clarification of concepts (Greenwood et al., 1995; Jenkins \& Jenkins, 1988; Topping, 1988; Wagner, 1990). Peer tutoring, as compared to conventional teachermediated instruction, increases (a) opportunities to respond, (b) academic engagement, and (c) relevant academic behaviors that are related to specific academic tasks (Greenwood \& Delquadri, 1995; Greenwood, Dinwiddie, Terry, et al., 1984).

The benefits of students in the roles of tutor and tutee operate at the cognitive, affective, evaluative, and behavioral levels (Foot et al., 1990; Gartner, Kohler, \& Riessman, 1971). At the cognitive level, tutors gain a deeper understanding of the material learned by having to teach it, and learning how to learn strategies may generalize to learning contexts other than the immediate learning task. At the affective level, tutoring may increase a sense of responsibility and concern for others. At an evaluative level, tutoring may enhance self-esteem and self-confidence. Last, at the behavioral level, tutoring may promote prosocial behaviors in students.

\section{Peer Tutor Training Requirements}

Peer tutoring strategies vary in the amount of training the interactors require. Peer tutoring strategies that require the tutor to employ a specific set of instructional behaviors have been reported to be more effective than those that only create pairs and then leave the tutoring procedures entirely to the tutor's discretion (Miller, Barbetta, \& Heron, 1994; Niedermeyer, 1970). Using structured interactions between tutors and tutees increases training requirements.

In general and special education classrooms, tutors typically are trained in the instructional practices they are to provide. Deterline (1970) enumerated the following 10 goals for tutor training, which are prescriptive of the teaching strategies that children with and without disabilities are expected to learn: (a) putting the tutee at ease; (b) clarifying the prescribed task; (c) showing the tutee how to verify his or her answer; (d) directing the tutee to read each problem aloud; (e) having the tutee respond overtly before the tutor provides feedback; (f) having the tutee verify each response; $(\mathrm{g})$ avoiding any form of punishment; (h) providing verbal praise when appropriate; (i) providing a tangible reward when appropriate; and (j) evaluating elements of mastery.

Training also may focus on materials to be used and what records of the tutee's performance are to be maintained. Tutor training for students without disabilities who participate as tutors for students with disabilities may include other kinds of information such as (a) an orientation describing cognitive, motivational, and behavioral characteristics of students with disabilities and how these characteristics may affect tutoring 
interactions, and (b) opportunities to observe students with disabilities before initiating a tutoring program observations (Whorton, Locke, Delquadri, \& Hall, 1989).

\section{Classroom Applications with Heterogeneous Student Populations}

Numerous research studies and reviews pertaining to peer tutoring and students with disabilities (ADHD, EMR, LD, BD, moderate-severe disabilities, and autism) in general and special education classrooms may be found in the literature (Agran, Fodor-Davis, Moore, \& Martella, 1992; Balenzano, Agte, McLaughlin, \& Howard, 1993; Beirne-Smith, 1991; Bell, Young, Blair, \& Nelson, 1990; Block, Oberweiser, \& Bain, 1995; Byrd, 1990; Campbell, Brady, \& Linehan, 1991; Cole, Vandercook, \& Rynders, 1988; Cooke, Heron, Heward, \& Test, 1982; Delquardri, Greenwood, Stretton, \& Hall, 1983; DuPaul \& Henningson, 1993; Fenrick \& Petersen, 1984; Franca, Kerr, Reitz, \& Lambert, 1990; Gable, Arllen, \& Hendrickson, 1994; Goodman, 1990; Gordon, Vaughn, \& Schumm, 1993; Greenwood, Delquadri, \& Hall, 1984; Greenwood, Terry, Utley, Montagna, \& Walker, 1993; Haper, Mallette, Maheady, Parkes, \& Moore, 1993; Hogan \& Prater, 1993, Kamps, Barbetta, Leonard, \& Delquadri, 1994; Kamps, Locke, Delquadri, \& Hall, 1989; Locke \& Fuchs, 1995; Maheady, Harper, \& Mallette, 1991; Maheady, Harper, \& Sacca, 1988; Maheady, Sacca, \& Harper, 1988; Mallette, Harper, Maheady, \& Dempsy, 1991; Marston, Deno, Kim, Diment, \& Rogers, 1995; Mathes \& Fuchs, 1993, 1994; Mathes, Fuchs, Fuchs, \& Henley, 1994; Odom \& Strain, 1984; Osguthorpe, Eiserman, \& Shisler, 1985; Osguthorpe \& Scruggs, 1986; Romer, Busse, Fewell, \& Vadasy, 1985; Santarsiero \& Rotatori, 1994; Scruggs \& Richter, 1988; Sideridis, 1995; Simmons, Fuchs, Fuchs, Hodge, \& Mathes, 1994; Yasutake, Bryan, \& Dohrn, 1996; Young, 1981).

This collective body of research supports the following conclusions: (a) peer tutoring is academically and socially beneficial for tutees and tutors alike; (b) benefits for tutors and tutees occur frequently and at consistently high rates; (c) students with disabilities can function effectively as tutors for other students; (d) the effects of peer tutoring interventions are aligned closely with the subject matter and reveal significant improvements in academic subjects; (e) social benefits are restricted to attitudes toward school, the academic content taught, and social interactions between tutors and tutees; and (f) the outcomes of peer tutoring strategies are related to the research design, experimental-control group comparisons, and pre-post treatment only group designs.

Peer tutoring strategies have been used effectively with students from ethnic, international, and multicultural/bilingual backgrounds (e.g., African-American and Hispanic-American groups) (Greenwood, Carta, Walker, Arreaga-Mayer, \& Dinwiddie, 1988; Greenwood, Delquadri, \& Hall, 1989; Harper, Mallette, \& Moore, 1991; King-Sears \& Bradley, 1995; Maheady, Mallette, \& Harper, 1991). Peer tutoring has occurred with multicultural/bilingual students of all languages, ages, achievement levels, socioeconomic levels, as well as diverse subject matter. Peer tutoring strategies with this population have been designed to meet a wide variety of purposes, including: (a) teaching basic skills in the primary and/or secondary languages, and (b) instructing students in foreign languages to allow for individualization, differential pacing through the curriculum, and to engage in supplementary drill and practice.

Because of the interactional context of tutoring, according to Greenwood et al., 1988, it is viewed as "particularly appropriate because second language acquisition naturally occurs in the context of talking to peers" (p. 6). The implementation of peer tutoring strategies results in many instructional and socioaffective benefits including the findings that (a) mastery learning in prespecified skill sequences is increased through practice and error correction opportunities; (b) communication skills are strengthened; (c) cross-cultural understanding occurs between tutors and tutees; and (d) positive relationships are established between second-language learners and fluent monolingual peers.

\section{Cross-Age Tutoring}

Cross-age tutoring is an innovative peer teaching program in which the tutors are students approximately two or more years older or younger than the students receiving the tutoring. The assumptions underlying this approach are that older students can benefit from tutoring experiences and they can effectively teach skills requiring individualized instruction (Gerber \& Kauffman, 1981; Schrader \& Valus, 1990; Topping, 1988). Research has demonstrated that older students with a range of disabilities have successfully tutored students with learning problems (Barbetta, Miller, Peters, Heron, \& Cochran, 1991; Polirstok \& Greer, 1986; Sindelar, 1982), students with LD (Kane \& Alley, 1980; Lazerson, Foster, Brown, \& Hummel, 1988), students with EMR (Csapo, 1976; Maher, 1984); students with severe disabilities (Vacc \& Cannon, 1991), mainstreamed students with disabilities (Folio \& Norman, 1981), and students with BD (Franca, 1983; Lane, Pollack, \& Sher, 1972; Maher, 1982, 1984; Osguthorpe \& Scruggs, 1986; Scruggs \& Osguthorpe, 1986).

In cross-age tutoring situations, according to Foot, Shute, Morgan, and Barron (1990), social relationships differ qualitatively and quantitatively from same-age interactions in that cross-age interactions enhance and expand the social skills for each individual. For instance, caretaking roles are more observable in interactions with younger children, whereas dependency and modeling are more observable in interactions with 
older children. Further, in tutoring younger students, older students can make appropriate accommodations in how they use language to teach skills (e.g., using simpler words and shorter sentences) and put more effort into teaching group problemsolving tasks to compensate for differences between themselves and other children.

Cross-age tutors may be selected from older children within the same school (Miller, Barbetta, \& Heron, 1994), nearby high schools (Barbetta et al., 1991), and universities and colleges (Miller, Miller, Armentrout, \& Flannagan, 1995). Implementing cross-age tutoring programs requires careful scheduling between teachers and students involved in the program. Teachers must arrange and establish suitable tutoring schedules and routines. Older tutors may be scheduled to work with younger students when their class is doing individual work so older students are not affected adversely by lost instructional time.

The training of cross-age tutors may consist of tutors' learning sign language, problem-solving skills, behavior management techniques, classroom survival skills, and task analysis procedures in addition to specific tutoring procedures, error correction, and social and positive reinforcement. The amount of time required to train cross-age tutors may range from 45 minutes (Barbetta et al., 1991) to 5 hours (Folio \& Norman, 1981 ) to 30 hours (Vacc \& Cannon, 1991) to 6 weeks (Haisley, Tell, \& Andrews, 1981).

The benefits of older students tutoring younger children are numerous. For counselors and teachers, cross-aged tutoring provides opportunities to (a) reduce behavior problems, (b) allow individualized instruction, (c) help motivate students, (d) bridge the gap between teacher and student, and (e) build academic skills. Advantages for older students working with younger students with and without disabilities are that they can (a) give encouragement for establishing good work habits, (b) interpret to younger students the rewards they will have in learning to work, (c) help meet younger students' needs to be successful, important, appreciated, and growing in skills, and (d) help younger students to overcome their fears and gain selfconfidence.

\section{Reverse-Role Tutoring}

Another innovative and promising peer-mediated approach is reverse-role tutoring, in which students with mild disabilities tutor younger students with and without disabilities. Because students with mild disabilities have proven to be effective tutors for younger students with disabilities, some researchers have hypothesized that they may be equally successful with younger students without disabilities (Maheady, Harper \& Mallette, 1991). In a series of studies of reverse-role tutoring, Top and Osguthorpe (1987), Shisler, Osguthorpe, and Eiserman (1987), and Eiserman, Shisler, and Osguthorpe (1987) studied the academic skills and self-concepts of older students with mild disabilities (i.e., EMR, LD, and BD) who tutored younger peers without disabilities. In one study, Top and Osguthorpe (1987) used a nonequivalent control-group design and showed that students with mild disabilities designated as tutors and their tutees (i.e., typical peers) made significant gains in reading achievement and that students with mild disabilities improved significantly in their perceptions of their academic competence. The subjects' self-concepts, however, showed no significant improvements.

Eiserman et al. (1987) reported the findings of a comprehensive review of 13 studies of reverse-role tutoring as follows: (a) students with EMR spent significantly more time with their typical peers during freeplay, interacted more with regular classroom peers, and increased their social interactions with typical peers; (b) students with LD showed significant gains in reading abilities, academic self-esteem, and attitudes about school and social acceptance; (c) students with BD were viewed more favorably by typical peers; and (d) students with $\mathrm{LD}$ and $\mathrm{BD}$ interacted more with their typical peers, made significant gains on criterion-referenced and standardized tests, improved their word attack skills, and increased their social acceptance among their typical peers.

Maheady, Mallette, \& Harper, (1991) outlined several advantages to assigning students with mild disabilities as tutors. These authors pointed out that students with mild disabilities (a) can function effectively as tutors and make substantial academic gains themselves; (b) may become instructional assets and resources for general classroom teachers; and (c) may dispel negative stereotypes about disabilities that have persisted among general educators.

\section{Group-Oriented Contingencies}

In the natural classroom environment, peers are one of the most powerful sources of behavior change agents in academic and social settings (Gable \& Arllen, \& Hendrickson, 1994). They also are unique sources of information because they have opportunities to observe, interact, and informally assess aspects of an individual's behavior (e.g., peer relations, friends, and sportsmanship) during parts of the school day that are unavailable to teachers and parents (Rusch, Rose, \& Greenwood, 1988). Further, the use of peers as behavior change agents may serve as a cue or as an aversive stimulus to: (a) facilitate academic accomplishments, (b) reduce instances of deviant and disruptive behavior, (c) increase work and study skills, (d) increase production and efficiency, and (e) teach social-interaction skills (Greenwood \& Hops, 1981; Salend, Reeder, Katz, \& Russell, 1992; Salend, Reid-Jantzen, \& Giek, 1992). 
Peer groups may consist of either typical/normally achieving students or students with disabilities in general and special education classrooms and may be categorized in the following ways: (a) peers are trained to be tutors or co-therapists in which they are taught to distribute points or reinforcers, record data, give instructions, and impose contingencies (Greenwood \& Hops, 1981; Greenwood, Sloane, \& Baskin, 1974), or (b) peers provide assistance through cooperative reinforcement contingencies in which they manipulate contingency arrangements so peers are given access to earned reinforcers and/or the reinforcement depends to some extent upon their behavior (Greenwood, Hops, Walker, et al., 1979).

Over the past 15 years, a behavioral technology - consisting of peer influence strategies and group-oriented contingencies-has emerged, with peers trained as social change agents in natural classroom settings. Peer influence strategies are those that take advantage of the natural social prompting and consequences that children in groups provide one another when working for a common goal or reward (Greenwood, Carta, \& Hall, 1988). More specifically, peer influence includes social behaviors such as spontaneous prompts and encouragement (Alexander, Corbett, \& Smigel, 1976), and assistance and spontaneous help to improve the performance of specific group members (Switzer, Deal, \& Bailey, 1977). When tasks allow, students perform various task components at which they are most skilled, leading to group products or outcomes (e.g., tutoring) (Delquadri et al., 1983; Kohler \& Greenwood, 1990; Greenwood, Dinwiddie, Bailey, et al., 1987; Polirstok \& Greer, 1986).

As defined by Rusch et al. (1988, p. 255), group-oriented contingencies refer to "reinforcement programs in which earning the reinforcer is contingent upon the whole class or subgroups of the class." Examples of group-oriented procedures include the use of (a) uniform and groupwide behavior requirements (rules) for all students rather than individuals, (b) consolidated recording measures (e.g., a total score earned by the group) and standard contingencies to save teacher time and effort, (c) standard, naturally available consequences for groups rather than individually tailored reinforcers (Kohler \& Greenwood, 1990), and (d) cooperative reward structures (Slavin, 1990). Utilizing group-oriented contingencies has several advantages over traditional methods of managing classroom behavior. Some of them are: (a) fostering group cohesiveness and cooperation among members, particularly culturally diverse students, (b) teaching responsibility to the group and enlisting support in solving classroom problems, (c) managing behavior efficiently and effectively, and (d) providing peers positive, practical, and appropriate methods for dealing with peer-related problems (Kohler, Strain, Hoyson, et al., 1995; Salend, 1994).

\section{Early Childhood Research}

One of the significant challenges facing early childhood education is the social integration of students with social and developmental delays. Research has addressed the social skills of young children with disabilities and consistently found that (a) these children are viewed by their typical peers to be less socially competent, (b) they experience more rejection on sociometric ratings than their typical peers, and (c) the sociometric rejections of these children often is represented in negative social interaction patterns during children's play activities. In preschool settings, a critical component of intervention programs for students with disabilities is social skills instruction involving the use of socially competent children to encourage or facilitate the social behavior of their classmates who exhibit delays (LeFebvre \& Strain, 1989; Twardosz, Nordquist, Simon, \& Botkin, 1983).

In reviewing the benefits of group-oriented contingencies, Kohler, Strain, Maretsky, and DeCesare (1990) and Kohler et al. (1995) noted that typical students and students with disabilities participating in these procedures exhibited corollary or untrained supportive behaviors. In the first Kohler et al. (1990) study, these authors examined the effects of individual and group-oriented reinforcement contingency procedures on the social and supportive interactions of two preschoolers with autism (ages 4 years old) and seven normally developing children (ages 3-4 years old) during dramatic play activities. Individual contingency procedures consisted of the teacher awarding Happy Faces to children who exchanged play organizers, shared, and offered assistance to other classmates. Group-oriented contingencies procedures consisted of the teacher pointing to a chart and showing a group of three elephants and stating, "Today is group day. To get a prize, every square on the Happy Face chart must be filled when the timer rings. That means that nobody gets a prize unless you earn all of your own Happy Faces and both of your friends earn all of the Happy Faces too." If one or more individuals did not meet this criterion, none of the children was permitted to select a reward. The results of this study showed that (a) individual and group-oriented contingencies both had equivalent effects on targeting children's social interaction with peers; (b) socially competent preschoolers exhibited few supportive prompts without direct training under group-oriented contingency conditions; and (c) socially competent children demonstrated high levels of supportive prompts after they had been taught to use these statements.

In the second study, Kohler et al. (1995) examined the effects of a modified peer-mediated strategy in which an entire class of preschoolers with disabilities and their typical peers received training for a wide range of diverse social skills and strategies. The participants were three preschoolers with autism (4 years old) and six of their typical classmates 
(3-5 years old) who were in engaged in manipulative play activities in groups of three (one target child and two socially competent peers). The peer-mediated intervention implemented was a programmed social skill training package developed by Odom, Kohler, and Strain (1987), in which all three target children and their peers learned the following skills: (a) play organizer suggestions, (b) share offers and requests, and (c) assistance, offers, and requests. Similar group reinforcement contingency procedures in the Kohler et al. (1990) study were implemented. In addition, classwide supportive skills were taught, whereby the target children and peers learned to remind one another to exchange, share, organize, and assist.

The results indicated that a comprehensive intervention package (a) increased the social interactions between the three students with autism and their typical peers, (b) socially competent preschoolers exchanged supportive prompts under group contingency conditions after they received training for these behaviors, and (c) supportive social interactions that contained supportive prompts were longer and more reciprocal in nature than those that did not.

\section{Students with Mild Disabilities}

Self-evaluation is one variation of group-oriented contingencies that decreases inappropriate behavior for students with BD (Rhodes, Morgan, \& Young, 1983), for high school students (Smith, Young, West, Morgan, \& Rhodes, 1988), for students with LD (McCurdy \& Shapiro, 1992), for students with serious emotional disturbance (Clark \& McKenzie, 1989), and for preschoolers with disabilities (Sainato, Strain, Lefebvre, \& Rapp, 1990). According to Hughes, Ruhl, and Misra (1989) and Salend, Whittaker, and Reeder (1992), self-evaluation requires "a student to compare his or her behavior to a set criterion and make a judgment about the quality or acceptability of the behavior" (p. 203).

In group contingency management systems, a group of students or individual student behaviors to be changed are demonstrated by the teacher and modeled by peers. Students are aware of the target behaviors, are able to monitor their own performance, and are aware that other students in their group are observing their behavior. At the end of the class period, students are given time to reflect on their own performance and progress.

In one study, Salend et al. (1992) investigated a group evaluation system with two different groups of adolescent students with LD and ED in reading and English classes. The target behaviors to be modified through the program were the students' inappropriate verbalizations. The group-evaluation management system included the following procedures: (a) a review, explanation, and demonstration of the salient features of the target behavior; (b) an opportunity for students to identify and present examples and nonexamples of the target behavior; (c) an explanation, demonstration, and role play of the groupevaluation system; and (d) an assessment of the students' understanding of the target behavior and the intervention.

The results indicated that each group of students worked collaboratively to determine the class's behavior through a consensus method in which they discussed each member's perspective. Some of the group members used self-recording procedures to count the number of inappropriate verbalizations. In summary, the authors demonstrated that the group-evaluation system is an effective peer-mediated strategy that can be employed efficiently in the classroom.

\section{INSTRUCTIONAL SYSTEMS BUILT AROUND PMII COMPONENTS}

In the last five to 10 years, several instructional systems have emerged with compelling and supporting research to make classroom instruction more responsive to diverse learners. These include ClassWide Peer Tutoring (CWPT) and variations such as Peer-Assisted Learning Strategies (PALS), Classwide Student Tutoring Teams (CSTT), and Reciprocal Peer Tutoring (RPT). These systems have been used to improve the effectiveness of pull-out instructional programs for students at-risk in urban elementary schools (i.e., RPT) and to improve the effectiveness of general classroom instruction in which students with disabilities have been included (e.g., CWPT, PALS, and CSTT).

\section{ClassWide Peer Tutoring (CWPT)}

Developed in the 1980s, CWPT is an instructional design that originated in the general education classroom as a means of improving the spelling accuracy of students who were lowachieving and categorized as LD. Because the teacher did not want to teach students in different ability groups, she used CWPT as a way to include all students in classroom spelling instruction. As a result of its initial success, CWPT soon was expanded to other content-area subjects such as reading, mathematics, and vocabulary (Delquadri et al., 1983).

To include all students in instruction, the design of CWPT sought to take full advantage of PMII components, specifically including one-on-one peer tutoring and group contingencies of reinforcement (see Table 2). Other PMII components included in CWPT were (a) modeling of correct responses as an errorcorrection strategy and (b) peer initiations (task presentations and response opportunities presented by the tutor, peer monitoring of performance, and checking and recording of points earned by the tutor). Additional instructional components taken 
from research on effective instruction included (a) frequent opportunities to respond and practice, (b) reciprocal tutor-tutee roles, (c) immediate error correction, (d) frequent testing, (e) posting of performance, and (f) feedback on progress, mastery and content coverage (Greenwood, Terry, Delquadri, Elliott, \& Arreaga-Mayer, 1995).

During CWPT sessions, all children are paired with a partner and each person is assigned to one of two competing teams. Tutor and tutee roles are reciprocal in that halfway through a session, tutors become tutees and vice-versa. The teacher's roles during these sessions are to supervise and monitor students' responding. Teachers are concerned with the quality of tutoring, and they award bonus points to tutors for using correct teaching behaviors. The teachers are concerned that the tutees are working quickly and that they are spelling words aloud as they write them.

Because of these components, CWPT is known be a system that engages the active academic responding of children focused on a specific subject matter lesson. Students commonly spend $60 \%$ to $80 \%$ of a session engaged in reading, writing, and talking about the subject matter. At the elementary school level, CWPT is designed to supplement traditional instruction and to replace seatwork, lecture, and oral reading group activities. At the secondary level, CWPT is focused on practice, skill building, and review of subject matter. Building and systemslevel procedures also are available for supporting the implementation of CWPT programs schoolwide.

CWPT reorganizes individual class members into tutor-tutee pairs working together on two competing teams. Tutees earn points for their team by responding to the tasks their tutors present. Tutors earn points from the teacher according to their implementation of the tutoring role. The teacher's implementation is guided by a manual of procedures (Greenwood, Delquadri, \& Carta, 1988; in press). The core procedures include:

- Review and introduction of new material to be learned

- Unit content materials to be tutored (e.g., reading passages, spelling word lists, or math fact lists)

- New partners each week

- Partner pairing strategies

- Reciprocal roles in each session

- Teams competing for the highest team point total

- Contingent individual tutee point earning

- Tutors providing immediate error correction

- Public posting of individual and team scores

- Social reward for the winning team

Added to these core procedures are subject matter specific procedures that accommodate peer teaching. For example, when applied to passage reading, tutees read brief passages from the curriculum to their tutor. The tutor provides points for correctly read sentences ( 2 points per sentence) and error correction (1 point per accurate correction). Teachers assess the fluency of the students' reading using oral reading rate measures.

When applied to reading comprehension, the tutee responds to who, what, when, where, and why questions provided by the tutor concerning the passage. The tutor corrects these responses, awards points, and gives feedback.

When applied to spelling, the tutee writes and spells words orally on a list. The tutor dictates the words to the tutee and corrects his or her performance. Similar variations are applied to vocabulary, mathematics, and silent reading, as well as seatwork activities.

CWPT lends itself to both teacher-prepared and standard commercial curriculum materials. CWPT enlists the rather extensive help and influence of the classroom peer group in the teaching process. Rewards of individual students in CWPT depend not just on their own performance but also on the collective performance of the individual's partner and team. Changing tutor-tutee pairs weekly and changing roles within daily sessions keep the children motivated. Each student also is provided with opportunities to learn teaching skills needed in the teacher's role.

At the end of the two tutoring sessions, students report their point totals to the teacher, who records them on their team chart. The totals are compared and both teams are applaudedthe winning team for winning and the losing team for an excellent effort. Following this are transitional activities to the next lesson to be taught.

Research on CWPT has shown that students at-risk and with mild disabilities acquire literacy skills at a faster rate, retain more of what they learn, and make greater advances in social competence when using CWPT compared to conventional instructional methods. This research (Greenwood, Terry, Delquadri, et al., 1995) has addressed the issue of who benefits from CWPT (e.g., LD, low-achieving/non-LD), how it can be applied widely within local schools using an administrative/ adoption model), and the role of technology (communication, training, and implementation quality information).

Perhaps the most dramatic findings have come from a 12year experimental, longitudinal study (Greenwood \& Delquadri, 1995). Results indicated that CWPT, compared to at-risk and a non-risk groups that did not receive CWPT (a) increased students' engagement during instruction, grades 1 to 3 (Greenwood, 1991a); (b) increased growth in student achievement at grades 2, 3, 4, and 6 (Greenwood, 1991b; Greenwood et al., 1989; Greenwood, Terry, et al., 1993); (c) reduced the number of CWPT students needing special education services by 7 th grade (Greenwood, Terry, et al., 1993), and (d) reduced the 
number of CWPT students dropping out of school by 11th grade (Greenwood \& Delquadri, 1995).

CWPT also has successfully been used as an integration strategy for a range of children with disabilities in addition to high-risk and students with LD. For example, Kamps et al. (1994) reported that CWPT improved the reading skills as well as peer interactions of students with autism and general education peers in an integrated setting. These students were a subgroup of high-functioning students with autism. They were children of normal intelligence but with serious deficits in social competence (e.g., rigid adherence to structure and schedules, a general disinterest in others, especially peers, and perseveration on objects or topics, or both).

DuPaul \& Henningson (1993) and Fiore and Becker (1994) reported that CWPT was effective for students with ADHD in general education classrooms and it has been recommended as an effective strategy for this population of students. Harper et al. (1993) demonstrated improvements in spelling for students with mild disabilities including generalization of the words learned during CWPT spelling instruction to writing tasks in the absence of specific training. Sideridis (1995) reported improvements in students' weekly spelling accuracy, time engaged, and peer social interaction for students with MR when using CWPT. Arreaga-Mayer (personal communication) currently completed work investigating the academic, language learning, and social benefits of CWPT adapted for students with limited English proficiency (LEP) and mild disabilities. In one study, she reported that English language use and practice were increased significantly when compared to traditional teacher-mediated instruction for LEP students with disabilities.

Consumers frequently have reported CWPT to be acceptable and useful.

This model [CWPT] has impacted over 500 students and 65 teachers, both regular and special education throughout the district. . . . It has resulted in students making greater gains, both academically and socially, compared to traditional pull-out models. Quality implementation, finding the time to provide training, new methods of assessment, and evaluating student progress are pressing issues in our district addressed by CWPT. We must refine, not reinvent our current knowledge and practice. This project provides the technology and the resources needed to make it happen. (comments of an inclusion coordinator)

We have used CWPT at every grade level with outstanding results. We have full inclusion of our special education population in regular education settings. ... . We continue to struggle with collaborative decision making, improvement in data management, and refinement of methods of assessment of student progress. Teachers use CWPT for reading and spelling in both literature and content settings. I have ap- plauded [Juniper Gardens'] focus on academically engaged time and the pragmatic approaches suggested for increasing that. The results indicated that those strategies have merit. (comments of an elementary school principal )

\section{Peer-Assisted Learning Strategies (PALS)}

Developed in the early 1990s, PALS was an effort to provide general education teachers an effective, feasible, and acceptable intervention for the entire class in which students with LD were included. In a series of studies, Fuchs, Fuchs, and Bishop (1992a, 1992b), Fuchs, Fuchs, Hamlett, Phillips, \& Bentz (1994), and Fuchs, Fuchs, Hamlett, Phillips, and Karns (1995) observed that general education teachers made fewer adaptations in their instruction to address the special needs of students with LD. This was the case even after teachers had been provided frequent information on the progress or lack of progress of individual students. To address the need for general educators to provide instruction across different types of learners, these authors recommended that general educators use curriculum-based measurement (CBM) within the context of classwide peer tutoring structures to differentiate instruction for students with $\mathrm{LD}$.

PALS is built around CWPT, but it includes a number of different learning strategies and, in some cases, it is linked to computerized CBM (Fuchs, Fuchs, Phillips, \& Karns, 1994). Thus, like CWPT, it joins PMII ingredients with the exception of peer networking to specific instructional tasks and strategies. PALS math, for example, provides teachers with group and individual reports on students' learning of specific math skills using classwide CBM. This enables teachers to gear instruction to the group as well as the needs of specific students. In the absence of CBM, teachers gear instruction to ability level groups of students and limited information is available for other students with diverse needs. PALS math instruction sessions last 40 minutes and may be implemented at least twice a week. The computer program identifies pairs of students (one who knows the skills and one who does not) to work together. This creates 13 to 15 unique pairings capable of working together all at the same time on individually tailored learning tasks instead of a single, whole-class, teacher-directed activity that may address the instructional needs of only a few students. PALS math tutoring is reciprocal, like CWPT, with each student in the role as a "player" and a "coach" during the session. The strongest student is identified as a coach first in the session, and the lower-performing student is identified as a player. Student pairings are changed every two weeks.

PALS math consists of skill coaching followed by practice. During coaching, the player solves a sheet of assigned problems. The coach guides the players responding by presenting a series of questions read from a prompt card. The questions 
break down the problem into its component parts (e.g., "Look at the sign, What kind of problem is it?"). The coach corrects responses and awards points much like CWPT. Midway through the sheet, they trade roles and continue. Practice follows after 15-20 minutes of coach. During practice, each student completes a problem sheet that contains easier problems combined with the problem type just coached. After 10-15 minutes, students exchange papers and correct the answers. The pair of students with the highest point total wins applause and the opportunity to collect the PALS folder, ending the session.

PALS reading is designed to be implemented three times per week during 35-minute sessions. Sessions are divided classwide activities that include: (a) partner reading, (b) paragraph shrinking, (c) prediction relays for 10 minutes each, and (d) a 2-minute story retelling after partner reading. The remaining few minutes are devoted to clean-up and transitional activities. Like PALS math, partners are formed to include high-performing and low-performing readers (heterogeneous pairs). From a ranking of students on reading ability, the strongest readers are assigned to tutor low-performing students.

Textbook materials are used during reading, and teachers may individualize reading materials for each pair, with a specific emphasis on the needs of the weaker reader. Like CWPT, both students read the assigned material. Both PALS and CWPT are designed to work with existing reading materials and approaches (e.g., phonics, whole language, or integrated reading methods).

During Partner Reading/Story Retell, the strongest student reads first (as a model) for 4 minutes; the lower-performing student reads the same material for 4 minutes; and then the lower-performing student sequences major events for 1-2 minutes. During Paragraph Shrinking, the higher-performing student resumes reading new text and stops after each paragraph to summarize the material for the next 4 minutes. The lowerperforming student continues with new material and summarizes each paragraph. Prompt cards are used to direct readers to answer comprehension questions (e.g., who, what, where, when and why) in 10 or fewer words. During Prediction Relay, students continue reading new textbook material with the stronger student reading aloud for 5 minutes and stopping after each page to summarize information and make a prediction about what will happen next. The lower-performing student follows same procedure over next 5 minutes. Students earn points from the coaches for reading each sentence correctly, for summarizing what they read, for making reasonable predictions, and for working cooperatively with their partner.

As was the case for CWPT, research on the effectiveness of PALS provides convincing support for its superiority compared to conventional general education instruction in reading and math. Results indicated that all students with and without LD made measurably greater progress on test scores in the same amount of time. Teachers and students both reported high levels of satisfaction with PALS instruction (Mathes, Fuchs, Fuchs, Henley, \& Sanders, 1994). In addition, these authors reported that students with LD were better liked, made friends, and were better known by peers during PALS instruction than in conventional teacher-led instruction. PALS reading and math also have won approval by the Program Effectiveness Panel, National Diffusion Network, and U.S. Department of Education.

\section{Classwide Student Tutoring Teams (CSTT)}

CSTT, a variation of CWPT, is designed for content-area classroom instruction at the secondary level (Maheady, Harper, Sacca, \& Mallette, 1991). It has been used as a means of improving students' mastery of skills and concepts the teacher has previously introduced. The mastery of basic subject matter skills allows the teacher more time to focus on teaching higherorder skills. Developed during the late 1980s (Maheady, Sacca, \& Harper, 1988), CSTT combined PMII ingredients (e.g., peer-teaching procedures of CWPT) with specific facets of the Teams-Games-Tournaments (TGT) program developed by Slavin and colleagues at John Hopkins University (DeVries \& Slavin, 1978; Harper, Mallette, Maheady, \& Brennan, 1993; Slavin, 1990).

As noted in the CSTT instructor's manual, a major antecedent requirement of CSTT is the development of study guides for the student teams (Maheady, Harper, \& Mallette, 1991). This involves identifying important units of instruction that correspond to the subject matter to be taught during the week. Each study guide consists of questions that elicit student responses of practice, recall, and application and that reflect content instructional goals. Short exams then are developed and given as pre-post indicators of unit learning outcomes. It also is recommended that CSTT be used in the context of clear classroom behavior rules and that students be fully taught how to work and fulfill the roles of a CSTT team member. This peer-mediated intervention incorporates content-related discussions and review to support instruction in mathematics, social studies, science, and history.

The success of CSTT can be attributed to the use of study guides as a review strategy for subject matter introduced previously. The peer teachers in each team use study guides to focus student attention and eliminate the guesswork about what must be learned (Harper, Maheady, \& Mallette, 1994). Thus, in contrast to CWPT and PALS, CSTT uses (a) three to five heterogeneous learning teams consisting of at least one high-, one average-, and one low-performing student to increase the probability and accuracy of peer teaching, help, and correction; and (b) teacher-developed study guides that identify the most 
important or relevant ideas, concepts, principles, or facts contained in each unit of instruction. The combination of these components seems to make CSTT effective, as well as interesting, to secondary-level teachers and older students.

In most academic environments, CSTT is relatively easy to implement. CSTT should be used after the instructional material has been presented and students have had the opportunity to discuss the content. CSTT may be incorporated into a teacher's instructional program twice a week with 30 minutes per session (Harper, Mallette, Maheady, \& Brennan, 1993; Harper, Maheady, \& Mallette, 1994; Maheady, Harper, Mallette, \& Winstanley, 1991).

During a CSTT session, each team is given a folder containing a study guide for the week, paper and pencils, and a small deck of cards. The cards are numbered in correspondence to items in the study guide. Students rotate taking turns as the teacher. The teacher draws a card from the deck of cards and reads the corresponding item to the teams (e.g., "What does empiricism mean?"). Each student writes his or her answer. The peer teacher then checks each teammate's response against the answer guide, awarding 5 points if correct or supplying the correct answer if in error. A student may receive 2 points if he or she corrects the error and successfully writes the correct response three times. When all answers have been corrected, the study guide is passed to the next student to the left and the top card is selected, thereby designating the next study question for the group's tutor to read. The team continues working. If time remains after completing 30 items, they reshuffle the deck and continue the activity to earn additional points.

Like CWPT and PALS, the teacher's role in CSTT is one of (a) monitoring team teaching and (b) awarding bonus points for teaching steps, good manners, and constructive, supporting comments between and among team members. The teacher times the sessions, answers questions, collects team points, and posts winning point totals on the board. The noncompetitive reward system in CSTT ensures that (a) all teams that meet a minimum standard are recognized by the teacher, (b) the most improved team is recognized, and (c) the most outstanding team members are recognized.

In a series of research studies, Maheady, Sacca, and Harper (1988) demonstrated the effectiveness of CSTT compared to teacher-mediated procedures. In one study, these authors compared the effects of CSTT and teacher-led instruction on the math performance of six classes of low-achieving ninth- and tenth-grade pupils enrolled in a special district program for potential dropouts. These mainstreamed classrooms contained 28 students with mild disabilities and 63 typical peers.

During CSTT instruction, the students' weekly math quiz scores increased by approximately 20 percentage points. The academic gains of the students with mild disabilities closely paralleled those of their typical peers. Students with and without disabilities were able to identify important content material and become better listeners. The students reported that they developed new friends and had more self-esteem.

\section{Reciprocal Peer Tutoring (RPT)}

Developed in the late 1980s, RPT has been used as a pullout program for serving low-achieving, high-risk students in urban elementary schools. RPT has compiled an impressive record of measurably superior results in the math achievement of students who typically tested between the 20th and 50th percentiles. RTP also was designed to take advantage of PMII components including peer teaching and the interdependence of pairs of learners produced by group reward systems. In RTP, as in CWPT, PALS, and CSTT, students serve as both teachers and students during tutoring sessions, and they follow a structured format of interacting with each other. Like PALS math, in RPT an initial 20-minute session reciprocal coaching period is followed by a 7-minute worksheet-testing session. Peers select rewards and performance goals from a list prepared by the teacher. Peers monitor and evaluate their own performance (Fantuzzo, King, \& Heller, 1992). Students are paired randomly in same-age dyads.

The students' responding in RPT is structured by four standard response opportunities for each problem (Try 1, Try 2, Help, and Try 3) (Fantuzzo, Davis, \& Ginsburg, 1995). The peer teacher presents the student a problem to solve using a flashcard with the answer on the back. The student computes the problem in writing on a structured worksheet similar to that used in CWPT math/spelling. If the first try is correct, the teacher praises the student and presents the next problem. If incorrect, the peer teacher provides structured help (as described on the answer side of the flashcard) and coaching. The student then attempts the problem at Try 2 . If still wrong, the teacher aide is called to coach the student in the correct-solution model, followed by a final effort by the student to solve it (i.e., Help). The student is provided an additional opportunity to solve the problem independently in Try 3 . Following 10 minutes of RPT, the pair switches roles and continues for another $10 \mathrm{~min}$ utes. Last, as an assessment of learning, 20 minutes of RPT is followed by a 16-problem quiz covering the material taught. Following this session, the individual accomplishments of each student are combined and compared to the student's predetermined goal. If the student exceeds that goal, he or she scores a "win" for the day. After five "wins," the pair is permitted to obtain the previously selected reward.

Early controlled evaluations of RPT have demonstrated significant academic gains in achievement, better social interac- 
tions, and less disruptive behavior (Pigott, Fantuzzo, \& Clement, 1986). Subsequent replications and applications also indicated significantly improved math achievement with RPT students for low-income minority and non-minority groups in urban schools (Fantuzzo, Polite, \& Grayson, 1990). In an investigation of the component procedures of RPT, Fantuzzo, King, \& Heller (1992) reported that students did best when the RPT program combined structured peer tutoring with the group reward components. The structured peer tutoring component provided tutors training in the use of a script defining their instructional interactions with each other. The group reward component provided students rewards contingent on the combined average performance of each partner pair rather than their individual performance. Students significantly increased their academic gains compared to students in structure only, group reward only, and no structure and no reward comparison groups.

These findings confirmed the importance of using an explicit, well designed peer teaching procedure (script) and not relying on the tutor's own unique method of teaching (Fuchs, 1996; Fuchs, Fuchs, Bentz, Phillips, \& Hamlett, 1994). And, by creating interdependence through the group reward system, it has been shown to make an important contribution to the overall effects of RPT in terms of increasing the concern, help, and support of the partner's progress during tutoring.

Recent studies have combined RPT at school with parent involvement at home. Heller and Fantuzzo (1993) and Fantuzzo, Davis, and Ginsburg (1995) reported that superior mathematics results on CBMs and standardized achievement tests were obtained by a group of African-American 4th- and 5th-grade students receiving both components compared to either one or a no-treatment control. Student receiving RPT rated themselves as more socially confident with peers than did students in the control group. Students and teachers in the RPT conditions rated their experiences highly.

\section{IMPLICATIONS AND CONCLUSIONS}

PMII components, when applied to the design of general education instruction, provide a major assist in terms of better managing group and individual student teaching and learning. For example, high teacher-pupil ratio has remained a major roadblock to individualization of general education instruction and its effectiveness for students with diverse needs. Peer tutoring formats and peer initiation training offer efficient alternatives for providing one-on-one instruction/intervention for specific time periods or for individualization.

The workload involved in managing general education instruction also has been a problem, hindering its effectiveness. Peer monitoring provides an efficient and effective method of correcting and providing feedback to students and of managing the paperwork involved in general education instruction. The extra time and planning needed to devote to developing children's social skills traditionally has been a problem in making general education more effective. Peer modeling, peer tutoring, and group-oriented contingencies are powerful strategies for supporting social skills instruction that do not need extra time or work during regular instructional times, and that have academic as well as social benefits. The difficulty in individualizing and adapting instruction to all students' needs has been a barrier to instructing students with special needs in the general education classroom. PMII components provide support that enables individualization and adaption commensurate with the needs of many students at-risk and with specific disabilities.

PMII components, when added to intervention in the general education classrooms, are effective for students with special needs. Research evidence also suggests that, perhaps more than previously thought possible, students without disabilities also benefit academically and socially in ways unique to utilization of PMII in both general and special education classrooms. Thus, we believe PMII components have and will continue to have important implications for improving the responsiveness and effectiveness of general education for all students.

Systems of instruction and intervention demonstrate the successful use of PMII components. PMII components have been integrated with other educational technologies, such as classwide CBM and effective teaching strategies, to form instructional systems that teachers and students say they prefer over traditional, teacher-mediated instruction. CWPT, PALS, CSTT, and RPT are increasingly sophisticated instructional systems, based on multiple studies and evaluations of over a decade of work, designed to overcome barriers, individualize instruction, and improve academic and social outcomes of students with disabilities in general education classrooms.

\section{REFERENCES}

Agran, M., Fodor-Davis, J., Moore, C., \& Martella, R. C. (1992). Effects of peer-delivered self-instructional training on a lunchmaking work task for students with severe disabilities. Education \& Training in Mental Retardation, 27(3), pp. 230-240.

Alexander, R. N., Corbett, T. F., \& Smigel, J. (1976). The effects of individual and group sequences on school attendance and curfew violations. Journal of Applied Behavior Analysis, 9, 221-226.

Antia, S. (1994). Strategies to develop peer interaction in young hearing-impaired children. Volta Review, 96, 277-290.

Apolloni, T., Cooke, S. A., \& Cooke, T. P. (1977). Establishing a normal peer as a behavioral model for developmentally delayed children. Perceptual \& Motor Skills, 44, 231-241.

Balenzano, S., Agte, L. J., McLaughlin, T. F., \& Howard, V. F. (1993). Training tutoring skills with preschool children with disabilities in a classroom setting. Child \& Family Behavior Therapy, 15(1), 1-36. 
Bandura, A. (1968). Social-learning theory of identificatory processes. In D. A. Goslin (Ed.), Handbook of socialization theory and research. Chicago: Rand McNally.

Barbetta, P. M., Miller, A. D., Peters, M. T., Heron, T. E., \& Cochran, L. L. (1991). Tugmate: A cross-age tutoring program to teach sight vocabulary. Education \& Treatment of Children, 14, 19-37.

Beirne-Smith, M. (1991). Peer tutoring in arithmetic for children with learning disabilities. Exceptional Children, 57, pp. 330-337.

Bell, K., Young, K. R., Blair, M., \& Nelson, R. (1990). Facilitating mainstreaming of students with behavioral disorders using classwide peer tutoring. School Psychology Review, 19, 564-573.

Brady, M. P., Shores, R. E., Gunter, P., McEvoy, M. A., Fox, J. J., \& White, C. (1984). Generalization of an adolescent's social interaction behavior via multiple peers in a classroom. Journal of the Association for Persons with Severe Handicaps, 9, 278-286.

Block, M. E., Oberweiser, B., \& Bain, M. (1995). Using classwide peer tutoring to facilitate inclusion of students with disabilities in regular physical education. Physical Educator, 52(1), 47-56.

Brophy, J. E. (1979). Teacher behavior and its effects. Journal of Educational Psychology, 71, 733-750.

Byrd, D. E. (1990). Peer tutoring with the learning disabled: A critical review. Journal of Education Research, 82(2), 115-118.

Campbell, B. J., Brady, M. P., \& Linehan, S. (1991). Effects of peermediated instruction on the acquisition and generalization of written capitalization skills. Journal of Learning Disabilities, 24(1), 6-14.

Carden-Smith, L. K., \& Fowler, S. A. (1984). Positive peer pressure: The effects of peer monitoring on children's disruptive behavior. Journal of Applied Behavior Analysis, 17, 213-227.

Chadsey-Rusch, J. (1986). Identifying and teaching valued social behaviors in competitive employment settings. In F. R. Rusch (Ed.), Competitive employment issues and strategies (pp. 273-287). Baltimore: Paul H. Brookes.

Clark, L. A., \& McKenzie, H. S. (1989). Effects of self-evaluation training of seriously emotionally disturbed children on the generalization of their classroom rule following and work behaviors across settings and teachers. Behavioral Disorders, 14, 89-98.

Cole, D. A., Vandercook, T., \& Rynders, J. (1988). Comparison of two peer interaction programs: Children with and without severe disabilities. American Educational Research Journal, 25, 415-439.

Cooke, N. L., Heron, T. E., Heward, W. L., \& Test, D. W. (1982). Integrating a Down's syndrome child in a classwide peer tutoring system. A case report. Mental Retardation, 20(1), 22-25.

Csapo, M. (1976). If you don't know it, teach it! Clearinghouse, 12(49), 365-367.

Cullinan, D., Sabornie, E. J., \& Crossland, C. L. (1992). Social mainstreaming of mildly handicapped students. Elementary School Journal, 92, 339-351.

Day, R., Powell, T., \& Dy-Lin, T. (1982). An evaluation of the effects of a social interaction training package on mentally handicapped preschool children. Education \& Training of the Mentally Retarded, 17, 125-130.

DeVries, D. L., \& Slavin, R. E., (1978). Teams-games-tournaments (TGT): Review of ten classroom experiments. Journal of Research \& Development in Education, 12, 28-38.
Delquadri, J., Greenwood, C. R., Stretton, K., \& Hall, R. V. (1983). The peer tutoring game: A classroom procedure for increasing opportunity to respond and spelling performance. Education and Treatment of Children, 6, 225-239.

Deterline, W. C. (1970). Training and management of students tutors. (Final Report). Palo Alto, CA: General Programmed Teaching. (ERIC Doc. Rep. No. ED 048-133).

Devoney, C., Guralnick, M. J., \& Rubin, M. (1974). Integrating handicapped and nonhandicapped preschool children: Effects on social play. Childhood Education, 50, 360-364.

DuPaul, G. J., \& Henningson, P. N. (1993). Peer tutoring effects on the classroom performance of children with attention deficit hyperactivity disorder. School psychology Review, 22(1), 134-143.

Eiserman, W. D., Shisler, L., \& Osguthorpe, R. T. (1987). Handicapped students as tutors: A description and integration of three years of research findings. B. C. Journal of Special Education, 2(3), 215-231.

Elliott, S. N., \& Gresham, F. M. (1993). Social skills interventions for children. Behavior Modification, 17, 287-313.

Fantuzzo, J. W., Davis, G. Y., \& Ginsburg, M. D. (1995). Effects of parent involvement in isolation or in combination with peer tutoring on student concept and mathematics achievement. Journal of Educational Psychology, 87, 272-281.

Fantuzzo, J. W., Jurecic, L., Stovall, A., Hightower, A. D., Goins, C., \& Schachtel, D. (1988). Using multiple peer exemplars to develop generalized social responding of a autistic girl. In. R. B. Rutherford \& C. M. Nelson (Eds.), Monograph in severe behavior disorders of children and youth (Vol. 7, pp. 17-26). Reston, VA: Council for Children with Behavioral Disorders.

Fantuzzo, J. W., King, J. A., \& Heller, L. R. (1992). Effects of reciprocal peer tutoring on mathematics and school adjustment: A component analysis. Journal of Educational Psychology, 84, 331-339.

Fantuzzo, J. W., Polite, K., \& Grayson, N. (1990). An evaluation of school-based reciprocal peer tutoring across elementary school settings. Journal of School Psychology, 28, 309-324.

Farmer, T. W., \& Cairns, R. (1991). Social networks and social status in emotionally disturbed children. Behavioral Disorders, 16, 288-298.

Fenrick, N. J. \& Petersen, T. K. (1984). Developing positive changes in attitudes towards moderately/severely handicapped students through a peer tutoring program. Education \& Training of the Mentally Retarded, 19(2), 83-90.

Field, T. (1984). Early peer relations. In P. S. Strain (Ed.), The utilization of classroom peers as behavior change agents (pp. 1-30). New York: Plenum Press.

Fiore, T. A., \& Becker, E. A. (1994). Promising classroom interventions for students with attention deficit disorders. Research Triangle Park, NC: Center for Research in Education, Research Triangle Institute. 
Folio, M. R., \& Norman, A. (1981). Toward more success in mainstreaming: A peer teacher approach to physical education. Teaching Exceptional Children, 13(3), 110-114.

Foot, H. C., Shute, R. H., Morgan M. J., \& Barron, A. M. (1990). Theoretical issues in peer tutoring. In H. C. Morgan, M. J. Shute, \& R. H. Shute (Eds.), Children helping children. (pp. 65-92). New York: John Wiley \& Sons.

Fowler, S. A. (1986). Peer-monitoring and self-monitoring: Alternatives to traditional teacher management. Exceptional Children, $52,573-583$.

Franca, V. M. (1983). Peer tutoring among behaviorally disordered students: Academic and social benefits to tutor and tutee. Dissertation Abstracts International, 44, 459-A.

Franca, V. M., Kerr, M. M., Reitz, A. L., \& Lambert, D. (1990). Peer tutoring among behaviorally disordered students: Academic and social benefits to tutor and tutee. Education \& Treatment of Children, 13(2), 109-128.

Fuchs, L. S. (1996). Models of classroom instruction: Implications for children with learning disabilities. In D. L. Speece \& B. K. Keogh (Eds.), Research on classroom ecologies: Implications for inclusion of children with learning disabilities (pp. 81-90). Mahwah, NJ: Lawrence Erlbaum.

Fuchs, L. S. Fuchs, D., Bentz, J., Phillips, N. B., \& Hamlett, C. L. (1994). The nature of student interactions during peer tutoring with and without training and experience. American Educational Research Journal, 31, 75-103.

Fuchs, L. S., Fuchs, D., \& Bishop, N. (1992a). Instructional adaptation for students at risk for academic failure. Journal of Education Research, 86, 70-84.

Fuchs, L. S., Fuchs, D., \& Bishop, N. (1992b). Teacher planning for students with learning disabilities: Differences between general and special educators. Learning Disabilities Research \& Practice, 7, 120-129.

Fuchs, L. S., Fuchs, D., Hamlett, C. L., Phillips, N., \& Bentz, J. (1994). Classwide curriculum-based measurement: Helping general educators meet the challenge of student diversity. Exceptional Children, 60, 518-537.

Fuchs, L. S., Fuchs, D., Hamlett, C. L., Phillips, N., \& Bentz, J. (1995). General educators' specialized adaptation for students with disabilities. Exceptional Children, 61, 440-459.

Fuchs, L. S., Fuchs, D., Phillips, N., \& Karns, K. (1994). Peer-mediated mathematics instruction: A manual. Nashville, TN: Peabody College of Vanderbilt University.

Furman, W., Rahe, D., \& Hartup, W. (1979). Rehabilitation of socially withdrawn preschool children through mixed-age and same-age socialization. Child Development, 50, 915-922.

Gable, R. A., Arllen, N. L., \& Hendrickson, J. M. (1994). Use of students with emotional/behavioral disorders as behavior change agents. Education \& Treatment of Children, 17(3), 267-276.

Garrison-Harrell, L. (1996). Utilization of a peer network strategy to teach social-communicative skills to elementary-age students with autism in a public school setting. Unpublished doctoral dissertation, University of Kansas, Lawrence.

Gartner, A., Kohler, M. C., \& Reissman, F. (1971). Children teach children: Learning by teaching. New York: Harper \& Row.
Gerber, M., \& Kauffman, J. M. (1981). Peer tutoring in academic settings. In P. S. Strain (Ed.), The utilization of classroom peers as behavior change agents (pp. 155-188). New York: Plenum Press.

Goetz, E. M., Ayala, J. M., Hatfield, V. L., Marshall, A. M., \& Etzel, B. C. (1983). Training independence in preschoolers with an auditory stimulus management technique. Education \& Treatment of Children, 6, 251-261.

Goldstein, H., \& Ferrell, D. (1987). Augmenting communicative interaction between handicapped and nonhandicapped preschool children. Journal of Speech \& Hearing Disorders, 52, 200-211.

Goldstein, H., Kaczmarek, L., Pennington, R., \& Shafer, K. (1992). Peer-mediated intervention: Attending to, commenting on, and acknowledging the behavior of preschoolers with autism. Journal of Applied Behavior Analysis, 25, 289-305.

Goldstein, H., \& Wickstrom, S. (1986). Peer intervention effects of communicative interaction among handicapped and nonhandicapped preschoolers. Journal of Applied Behavior Analysis, 199, 209-214.

Goodlad, J. I., \& Lovitt, T. C. (1993). Integrating general and special education. New York: Merrill.

Goodman, L. (1990). Time and learning in the special education classroom. Albany, NY: SUNY Press.

Gordon, J., Vaughn, S., \& Schumm, J. S. (1993). Spelling interventions: A review of literature and implications for instruction for students with learning disabilities. Learning Disabilities Research \& Practice, 8(3), 175-181.

Greenwood, C. R. (1991a). Classwide peer tutoring: Longitudinal effects on the reading, language, and mathematics achievement of at-risk students. Journal of Reading, Writing, and Learning Disabilities International, 7(2), 105-123.

Greenwood, C. R. (1991b). Longitudinal analysis of time, engagement, and achievement of at-risk versus non-risk students. Exceptional Children, 57(6), 521-532.

Greenwood, C. R. (1996). Research on the practices and behavior of effective teachers at the Juniper Gardens Children's Project: Implication for the education of diverse learners. In D. L. Speece \& B. K. Keogh (Eds.), Research on classroom ecologies: Implications for inclusion of children with learning disabilities (pp. 39-67). Mahwah, NJ: Lawrence Erlbaum.

Greenwood, C. R., Carta, J. J., \& Hall, R. V. (1988). The use of peer tutoring strategies in classroom management and educational instruction. School Psychology Review, 17, 258-275.

Greenwood, C. R. Carta, J. J., \& Kamps, D. (1990). Teacher-mediated versus peer-mediated instruction: A review of educational advantages and disadvantages. In H. C. Foot, M. J. Morgan, \& R. H. Shute (Eds.), Children helping children. New York: John Wiley \& Sons.

Greenwood, C. R., Carta, J. J., Walker, D., Arreaga-Mayer, C., \& Dinwiddie, G. (1988). Peer tutoring: Special education. In T. Husen \& T. N. Postlethwaite (Eds.), The international encyclopedia of education: Research and studies (Supplementary Vol. 1) (pp. 1-9). New York: Pergamon Press. 
Greenwood, C. R., \& Delquadri, J. (1995). ClassWide peer tutoring and the prevention of school failure. Preventing School Failure, 39(4), 21-25.

Greenwood, C. R., \& Delquadri, J. C., \& Hall, R. V. (1984). Opportunity to respond and student academic performance. In W. L. Heward, T. E. Heron, J. Trap-Porter, \& D. S. Hill (Eds.), Focus on behavior analysis in education (pp. 58-88). Columbus, $\mathrm{OH}$ : Charles Merrill.

Greenwood, C. R., \& Delquadri, J. C., \& Hall, R. V. (1989). Longitudinal effects of Classwide peer tutoring. Journal of Educational Psychology, 81, 371-383.

Greenwood, C. R., Delquadri, J., \& Carta, J. J. (in press). ClassWide Peer Tutoring (CWPT) for teachers. Longmont, CO: Sopris West.

Greenwood, C. R., Dinwiddie, G., Bailey, V., Carta, J. J., Dorsey, D., Kohler, F. W., Nelson, C., Rotholtz, D., \& Schulte, D. (1987). Field replication of Classwide peer tutoring. Journal of Applied Behavior Analysis, 20, 151-160.

Greenwood, C. R., Dinwiddie, G., Terry, B., Wade, L., Stanley, S., Thibadeau, S., \& Delquadri, J. (1984). Teacher-versus peer-mediated instruction: An eco-behavioral analysis of achievement outcomes. Journal of Applied Behavior Analysis, 17, 521-538.

Greenwood, C. R., \& Hops, H. (1981). Group-oriented contingencies and peer behavior change. In P. S. Strain, The utilization of classroom peers as behavior change agents (pp. 189-259). New York: Plenum Press.

Greenwood, C. R., Hops, H., Walker, H., Guild, J., Stokes, J., Young, K. R., Keleman, K., \& Willardson, M. (1979). Standardized classroom management program: Social validation and replication studies in Utah and Oregon. Journal of Applied Behavior Analysis, 12, 235-253.

Greenwood, C. R., Sloane, H. N., \& Baskin, A. (1974). Training elementary-aged peer behavior managers to control small group programmed mathematics. Journal of Applied Behavior Analysis, $1,1-12$.

Greenwood, C. R., Terry, B., Delquadri, J., Elliott, M., \& ArreagaMayer, C. (1995). ClassWide Peer Tutoring (CWPT): Effective teaching and research review. Kansas City, KS: Juniper Gardens Children's Project.

Greenwood, C. R., Terry, B., Utley, C. A. Montagna, D, \& Walker, D. (1993). Achievement, placement, and services: Middle school benefits of Classwide peer tutoring used at the elementary school. School Psychology Review, 22(3), 497-516.

Guralnick, M. J. (1976). The value of integrating handicapped and nonhandicapped preschool children. American Journal of Orthopsychiatry, 42, 236-245.

Haisley, F. B., Tell, C. A., \& Andrews, J. (1981). Peers as tutors in the mainstream: Trained "teachers" of handicapped adolescents. Journal of Learning Disabilities, 14, 224-226.

Handlan, S., \& Bloom, L. A. (1993). The effects of educational curricula and modeling/coaching on the interactions of kindergarten children with their peers with autism. Focus on Autistic Behavior, 8, 1-11.

Haring, T. G., \& Breen, C. B. (1992). A peer-mediated social network intervention to enhance the social integration of persons with moderate and severe disabilities. Journal of Applied Behavior Analysis, 25, 319-333.

Harper, G. F., Maheady, L., \& Mallette, B. (1994). The power of peer-mediated instruction: Why and how does it promote success for all students? In J. S. Thousand, R. A. Villa, \& A. I. Nevin (Eds.), Creativity and collaborative learning: A practical guide to empowering students (pp. 229-241). Baltimore: Paul H. Brookes.

Harper, G. R., Mallette, B., \& Maheady, L. (1995, November). Peermediated instruction and multicultural child with mild disabilities. Paper presented at annual meeting of Hawaii Federation Council for Exceptional Children, Honolulu.

Harper, G. F., Mallette, B., Maheady, L., \& Brennan, G. (1993). Classwide student tutoring teams and direct instruction as a combined instructional program to teach generalizable strategies for mathematics word problems. Education \& Treatment of Children, 16, 115-134.

Harper, G. F., Mallette, B., \& Moore, J. (1991). Peer-mediated instruction: Teaching spelling to primary school children with mild disabilities. Journal of Reading, Writing, \& Learning Disabilities International, 7(3), 137-151.

Harper, G. F., Mallette, B., Maheady, L., Bentley, A. E., \& Moore, J. (1995). Retention and treatment failure in Classwide peer tutoring: Implications for further research. Journal of Behavioral Education, 5(4), 399-414.

Harper, G. F., Mallette, B., Maheady, L., Parkes, V., \& Moore, J. (1993). Retention and generalization of spelling words acquired using a peer-mediated instructional procedure by children with mild handicapping conditions. Journal of Behavioral Education, 3(1), 25-38.

Hecimovic, A., Fox, J. J., Shores, R. E., \& Strain, P. S. (1985). An analysis of developmentally integrated and segregated freeplay settings and the generalization of newly acquired social behaviors of socially withdrawn preschoolers. Behavior Assessment, 7, 367-388.

Heller, L. R., \& Fantuzzo, J. W. (1993). Reciprocal peer tutoring and parent partnership: Does parent involvement make a difference? School Psychology Review, 22, 517-534.

Heller, K. A., Holtzman, W. H., \& Messick, S. (1982). Placing children in special education: A strategy for equity. Washington, DC: National Academy Press.

Hogan, S., \& Prater, M. A. (1993). The effects of peer tutoring and self-management training on on-task, academic, and disruptive behaviors. Behavioral Disorders, 18(2), 118-128.

Hollin, C. R., \& Trower, P. (1988). Development and applications of social skills training: A review and critique. In M. Hersen, R. M. Eisler, \& P. M. Miller (Eds.), Progress in behavior modification (Vol. 22, pp. 165-214). Newbury Park, CA: Sage.

Horner, R., Meyer, L. H., \& Fredericks, H. D. (1987). Education of learners with severe handicaps: Exemplary service strategies. Baltimore: Paul H. Brookes.

Hughes, C. A., Ruhl, K. L. \& Misra, A. (1989). Self-management with behaviorally disordered students in school settings: A promise unfulfilled? Behavioral Disorders, 14, 250, 262. 
Jakibchuck, A., \& Smeriglio, V. L. (1976). The influence of symbolic modeling on the social behavior of preschool children with low levels of social responsiveness. Child Development, 47, 838-841.

Jenkins, J. R., \& Jenkins, L. M. (1988). Peer tutoring in elementary and secondary programs. Focus on Exceptional Children, 17, 10-12.

Kalfus, G. R. (1984). Peer mediated intervention: A critical review. Child \& Family Behavior Therapy, 6, 17-43.

Kamps, D. M., Barbetta, P. M., Leonard, B. R., \& Delquadri, J. (1994). Classwide peer tutoring: An integration strategy to improve and promote peer interactions among students with autism and general education peers. Special section: Behavior analysis in school psychology. Journal of Applied Behavior Analysis, 27(1), 49-61.

Kamps, D. M., Leonard, B. R., Vernon, S., Dugan, E. P. \& Delquadri, J. (1992). Teaching social skills to students with autism to increase peer interactions in an integrated first-grade classroom. Journal of Applied Behavior Analysis, 25, 281-288.

Kamps, D. M., Locke, P., Delquadri, J., \& Hall, R. V. (1989). Increasing academic skills of student with autism using fifth grade peers as tutors. Education \& Treatment of Children, 12(1), 38-51.

Kane, B. J., \& Alley, G. R. (1980). A peer-tutored, instructional management program in computational mathematics for incarcerated, learning disabled juvenile delinquents. Journal of Learning Disabilities, 13, 148-151.

Keller, F. S. (1968). “Good-bye teacher...” Journal of Applied Behavior Analysis, 1, 79-89.

King-Sears, M. E., \& Bradley, D. F. (1995). ClassWide peer tutoring: Heterogeneous instruction in general education classrooms. Preventing School Failure, 40(1), 29-35.

Kohler, F. W., \& Greenwood, C. R. (1990). Effects of collateral peer supportive behaviors within the classwide peer tutoring program. Journal of Applied Behavior Analysis, 23(3), 307-322.

Kohler, F. W., Schwartz, I. S., Cross, J. A. \& Fowler, S. A. (1989). The effects of two alternating peer invention roles on independent work skills. Education \& Treatment of Children, 12(3), 205-218.

Kohler, F. W., Strain, P. S., Hoyson, M., Davis, L., Donina, W. M., \& Rapp, N. (1995). Using a group-oriented contingency to increase social interactions between children with autism and their peers. Behavior Modification, 19(1), 10-32.

Kohler, F. W., Strain, P. S., Maretsky, S., \& DeCesare, L. (1990). Promoting positive and supportive interactions between preschoolers: An analysis of group-oriented contingencies. Journal of Early Intervention, 14(4), 327-341.

Kornhaber, R. C., \& Schroeder, H. E. (1975). Importance of model similarity on extinction of avoidance behavior in children. Journal of Consulting \& Clinical Psychology, 43, 601-607.

Lane, P., Pollack, C., \& Sher, N. (1972). Remotivation of disruptive adolescents. Journal of Reading, 15, 351-354.

Lazerson, D. B., Foster, H. L., Brown, S. I., \& Hummel, J. W. (1988). The effectiveness of cross-age tutoring with truant, junior high students with learning disabilities. Journal of Learning Disabilities, 21, 253-255.
LeFebvre, D., \& Strain, P. S. (1989). Effects of a group contingency on the frequency of social interactions among autistic and nonhandicapped preschool children: Making LRE efficacious. Journal of Early Intervention, 13, 329-341.

Locke, W. R., \& Fuchs, L. S. (1995). Effects of peer-mediated reading instruction on the on-task behavior and social interaction of children with behavior disorders. Journal of Emotional and Behavioral Disorders, 3, 92-99.

Maheady, L., \& Harper, G. (1987). A classwide peer tutoring program to improve the spelling test performance of low-income, thirdand fourth-grade students. Education and Treatment of Children, 10, 120-133.

Maheady, L., Harper, G. F., \& Mallette, B. (1991). Peer-mediated instruction: A review of potential applications for special education. Reading, Writing, \& Learning Disabilities, 7, 75-103.

Maheady, L., Harper, G., Mallette, B., \& Winstanley, N. (1991). Training and implementation requirements associated with the use of a classwide peer tutoring system. Education \& Treatment of Children, 14, 177-189.

Maheady, L., Harper, G. F., \& Sacca, M. K. (1988). Classwide peer tutoring programs in secondary self-contained programs for the mildly handicapped. Journal of Research \& Development in Education, 21(3), 76-83.

Maheady, L., Harper, G. F., \& Sacca, M. K. (1988). Peer-mediated instruction: A promising approach to meeting the diverse needs of LD adolescents. Learning Disability Quarterly, 11(2), 108-113.

Maheady, L., Harper, G. F., Sacca, M. K., \& Mallette, B. (1991). Classwide student tutoring teams (CSTT): Instructor's manual. Fredonia, NY: State University of New York, College at Fredonia.

Maheady, L., Mallette, B., \& Harper, G. F. (1991). Accommodating cultural, linguistic, and academic diversity: Some peer-mediated instructional options. Preventing School Failure, 36(1), 28-31.

Maheady, L., Sacca, M. K., \& Harper, G. F. (1988). The effects of a classwide peer tutoring program on the academic performance of mildly handicapped students enrolled in 10th grade social studies classes. Exceptional Children, 55, 52-59

Maher, C. A. (1982). Behavioral effects of using conduct problem adolescents as cross-age tutors. Psychology in the School, 19, 360-364.

Maher, C. A. (1984). Handicapped adolescents as cross-age tutors: Program description and evaluation. Exceptional Children, 51, 51-63.

Mallette, B., Harper, G. F., Maheady, L., \& Dempsy, M. (1991). Retention of spelling words acquired using a peer-mediated instructional strategy. Education \& Training in Mental Retardation, 156-164.

Marston, D., Deno, S. L., Kim, D., Diment, K., \& Rogers, D. (1995). Comparison of reading intervention approaches for students with mild disabilities. Exceptional Children, 62(1), 20-37.

Mathes, P. G., \& Fuchs, L. S. (1993). Peer-mediated reading instruction in special education resource rooms. Learning Disability Research \& Practice, 8(4), 233-243. 
Mathes, P. G., \& Fuchs, L. S. (1994). The efficacy of peer tutoring in reading for students with disabilities: A best-evidence synthesis. School Psychology Review, 23(1), 59-80.

Mathes, P. G., Fuchs, D., Fuchs, L. S., Henley, A. M. (1994). Increasing strategic reading practice with Peabody classwide peer tutoring. Learning Disabilities Research \& Practice, 9(1), 44-48.

Mathur, S. R., \& Rutherford, R. B. (1991). Peer-mediated interventions promoting social skills of children and youth with behavioral disorders. Education \& Treatment of Children, 14, 227-242.

Matson, J. L., Fee, V. E., Coe, D. A., \& Smith, D. (1991). A social skills program for developmentally delayed preschoolers. Journal of Clinical Child Psychology, 20, 428-433.

McCurdy, B. L., \& Shapiro, E. S., (1992). A comparison of teacher-, peer, and self-monitoring with curriculum-based measurement in reading among students with learning disabilities. Journal of Special Education, 26(2), 162-180.

McEvoy, M. A., \& Odom, S. L. (1987). Social interaction training for preschool children with behavioral disorders. Behavioral Disorders, 12, 242-251.

McEvoy, M. A., Odom, S. L., \& McConnell, S. R. (1992). Peer social competence intervention for young children with disabilities. In S. L. Odom, S. R., McConnell, \& M. A. McEvoy (Eds.), Social competence of young children with disabilities (pp. 113-133). Baltimore: Paul H. Brookes.

McHale, S. (1983). Social intervention of autistic and nonhandicapped children during freeplay. American Journal of Orthopsychiatry, 53, 81-91.

Miller, A. D., Barbetta, P. M., \& Heron, T. E. (1994). START tutoring: Designing, training, implementing, adapting, and evaluating tutoring programs for school and home settings. In W. L. Heward, T. E. Heron, D. S. Hill, \& J. Trap-Porter (Eds.), Focus on behavior analysis in education (pp. 265-282). Englewood Cliffs, NJ: Merrili/Prentice Hall.

Miller, S. R., Miller, P. M., Armentrout, J. A., \& Flannagan, J. W. (1995). Cross-age tutoring: A strategy for promoting self-determination in students with severe emotional disabilities/behavior disorders. Preventing School Failure, 39(4), 32-37.

Nelson, J. R., Smith, D. J., \& Colvin, G. (1995). The effects of a peermediated self-evaluation procedure on the recess behavior of students with behavior problems. Remedial \& Special Education, 16(2), 117-126.

Niedermeyer, F. C. (1970). Effects of training on the instructional behaviors of student tutors. Journal of Educational Research, 64, 119-123.

O'Conner, R. D. (1972). The relative efficacy of modeling, shaping, and the combined procedures for the modification of social withdrawal. Journal of Abnormal Psychology, 79, 327-334.

Odom, S., Kohler, F. W., \& Strain, P. S. (1987). Teaching strategies for promoting social interaction skills. Unpublished manuscript, University of Pittsburgh, Early Childhood Research Institute.

Odom, S. L., \& Strain, P. S. (1984). Peer-mediated approaches to promoting children's social interaction: A review. American Journal of Orthopsychiatry, 54, 544-557.
Odom, S. L., Hoyson, M., Jamieson, B., \& Strain, P. S. (1985). Increasing handicapped preschoolers' peer social interactions: Cross setting and component analysis. Journal of Applied Behavior Analysis, 18, 3-16.

Odom, S. L., \& Strain, P. S. (1984). Peer-mediated approaches to promoting children's social interaction: A review. American Journal of Orthopsychiatry, 54, 544-557.

Odom, S. L., \& Strain, P. S. (1986). A comparison of peer initiation and teacher-antecedent interventions for promoting reciprocal social interaction of autistic preschoolers. Journal of Applied Behavior Analysis, 19, 59-72.

Odom, S. L., Strain, P. S., Karger, M. A., \& Smith, J. D. (1986). Using single and multiple peers to promote social interaction of preschool children with handicaps. Journal of the Division for Early Childhood, 10, 53-64.

Osguthorpe, R. T., Eiserman, W. D., \& Shisler, L. (1985). Increasing social acceptance: Mentally retarded students tutoring regular class peers. Education \& Training of the Mentally Retarded, 20(4), 235-240.

Osguthorpe, R. T., \& Scruggs, T. E. (1986). Special education students as tutors: A review and analysis. Remedial \& Special Education, 7(4), 15-26.

Ostrosky, M. M., \& Kaiser, A. P. (1995). The effects of a peer-mediated intervention on the social communicative interactions between children with and without special needs. Journal of Behavioral Education, 5(2), 151-171.

Piggott, H. E., Fantuzzo, J. W., \& Clement, P. (1986). The effects of reciprocal peer tutoring and group contingencies on the academic performance of elementary school children. Journal of Applied Behavior Analysis, 19, 93-98.

Polirstok, S. R., \& Greer, R. D. (1986). A replication of collateral effects and a component analysis of a successful tutoring package for inner-city adolescents. Education \& Treatment of Children, 9, 101-121.

Rhode, G., Morgan, D. P., \& Young, K. R. (1983). Generalization and maintenance of treatment gains of behaviorally handicapped students from resource rooms to regular classrooms using self-evaluation procedures. Journal of Applied Behavior Analysis, 16, 171-187.

Romer, L. T., Busse, D. G., Fewell, R., \& Vadasy, P. F. (1985). The relative effectiveness of special education teachers and peer tutors. Education of the Visually Handicapped, 17(3), 99-115.

Rucker, C. N., \& Vincenzo, F. M. (1970). Maintaining social acceptance gains made by mentally retarded children. Exceptional Children, 36, 679-680.

Rusch, F. R., Rose, T., \& Greenwood, C. R. (1988). Introduction to behavior analysis in special education. Englewood Cliffs, $\mathrm{NJ}$ : Prentice Hall.

Sainato, D. M. (1990). Classroom transitions: Organizing environments to promote independent performance in preschool children with disabilities. Education \& Treatment of Children, 13(4), 288-297.

Sainato, D. M., Strain, P. S., LeFebvre, D., \& Rapp, N. (1987). Facilitating transition times with handicapped preschool children: A 
comparison between peer-mediated and antecedent prompt procedures. Journal of Applied Behavior Analysis, 20, 285-291.

Sainato, D. M., Strain, P. S., LeFebvre, D., \& Rapp, N. (1990). Effects of self-evaluation on the independent work skills of preschool children. Exceptional Children, 56, 540-549.

Salend, S. J. (1994). Effective mainstreaming: Creating inclusive classrooms. New York: Macmillan.

Salend, S. J., Reeder, E., Katz, N., \& Russell, T. (1992). The effects of a dependent group-evaluation system. Education \& Treatment of Children, 15(1), 32-42.

Salend, S. J., Reid-Jantzen, N., \& Giek, K. (1992). Using a peer confrontation system in a group setting. Behavioral Disorders, 13(3), 211-218.

Salend, S. J., Whittaker, C. R., \& Reeder, E. (1992). Group evaluation: A collaborative, peer-mediated behavior management system. Exceptional Children, 59(3), 203-209.

Santarsiero, W. A., \& Rotatori, A. F. (1994). Cooperative learning, peer tutoring, peer collaboration, and peer support in the REI. In A. F. Rotatori, J. O. Schwenn, \& F. W. Litton (Eds.), Advances in special education: Perspectives on the regular education initiative and transitional programs (Vol. 8, pp. 75-106). Greenwich, CT: JAI Press.

Sasso, G. M., Garrison-Harrell, L., \& Rogers, L. (1994). The conceptualization of socialization and autism. In Scruggs, T. E. \& Mastroperi, M. A. (Eds.), Relevant research issues in developmental disabilities (pp. 161-175). New York: Plenum Press.

Schrader, B., \& Valus, V. (1990). Disabled learners as able teachers: A cross-age tutoring project. Academic Therapy, 25, 589-597.

Scruggs, T. E., \& Osguthorpe, R. T. (1986). Tutoring interventions within special education settings: A comparison of cross-age and peer tutoring. Psychology in the Schools, 23, 187-193.

Scruggs, T. E., \& Richter, L. (1988). Tutoring learning disabled students: A critical review. Learning Disability Quarterly, 2, 274-286.

Shafer, M. S., Engel, A. L., \& Neef, N. A. (1984). Training mildly handicapped peers to facilitate changes in the social interaction skills of autistic children. Journal of Applied Behavior Analysis, $17,461-476$.

Shisler, L., Osguthorpe, R. T., \& Eiserman, W. D. (1987). The effects of reverse-role tutoring on the social acceptance of students with behavioral disorders. Behavioral Disorders, 35-44.

Sideridis, G. D. (1995). Classwide peer tutoring: Effects on the spelling performance of social interactions of students with mild disabilities and their typical peers in an integrated instructional setting. Unpublished doctoral dissertation, University of Kansas, Lawrence.

Simmons, D. C., Fuchs, D., Fuchs, L. S., Hodge, J. P., \& Mathes, P. G. (1994). Importance of instructional complexity and role reciprocity to classwide peer tutoring. Learning Disabilities Research \& Practice, 9(4), 203-212.

Sindelar, P. T. (1982). The effects of cross-aged tutoring on the comprehension skills of remedial reading students. Journal of Special Education, 16(2), 199-206.

Siperstein, G. N. (1992). Social competence: An important construct in mental retardation. American Journal on Mental Retardation, 966, iii-vi.
Slavin, R. E. (1990). Cooperative learning: Theory, research, and practice. Englewood Cliffs, NJ: Prentice Hall.

Smith, D. J., Nelson, J. R., Young, K. R., \& West, R. P. (1992). The effect of a self-management procedure on the classroom and academic behavior of students with mild handicaps. School Psychology Review, 21(1), 59-72.

Smith, D. J., Young, K. R., West, R. P., Morgan, D. P., Rhode, G. (1988). Reducing the disruptive behavior of junior high students: A classroom self-management procedure. Behavior Disorders, 13(4), 231-239.

Stainback, W., \& Stainback, S. (1996). Controversial issues confronting special education: Divergent perspectives. Needham Heights, MA: Allyn \& Bacon.

Storey, K., Smith, D. J., \& Strain, P. S. (1993). Use of classroom assistants and peer-mediated interventions to increase integration in preschool settings. Exceptionality, 4, 1-16.

Strain, P. (1981). The utilization of classroom peers as behavior change agents. New York: Plenum Press.

Strain, P. S., Kerr, M. M., \& Ragland, E. U. (1979). Effects of peermediated social initiations and prompting/reinforcement procedures on the social behavior of autistic children. Journal of Autism \& Developmental Disorders, 9, 41-54.

Strain, P. S., \& Odom, S. L. (1986). Effective intervention for social skills development of exceptional children. Exceptional Children, 52, 543-551.

Strain, P. S., Shores, R. E., \& Timm, M. (1977). Effects of peer social initiations on the behavior of withdrawn preschool children. Journal of Applied Behavior Analysis, 10, 289-298.

Switzer, E. B., Deal, T. E., \& Bailey, J. S. (1977). The reduction of stealing in second graders using a group contingency. Journal of Applied Behavior Analysis, 10, 267-272.

Top, B. L., \& Osguthorpe, R. T. (1987). Reverse-role tutoring: The effects of handicapped students tutoring regular class students. $E l$ ementary School Journal, 87(4), $414-423$.

Topping, K. (1988). The peer tutoring handbook: Promoting cooperative learning. London: Croom Helm.

Twardosz, S., Nordquist, V. M., Simon, R., \& Botkin, D. (1983). The effect of group affection activities on the interaction of socially isolated children. Analysis \& Intervention in Developmental Disabilities, 3, 311-338.

Vacc, N. N., \& Cannon, S. J. (1991). Cross-age tutoring in mathematics: Sixth graders helping students who are moderately handicapped. Education \& Training of the Mentally Retarded, 26, 89-97.

Vaughn, S., \& Lancelotta, G. X. (1990). Teaching interpersonal social skills to poorly accepted students: Peer-pairing versus non-peerpairing. Journal of School Psychology, 28, 181-188.

Wagner, L. (1990). Social and historical perspectives on peer teaching in education. In H. C. Foot, M. J. Morgan, \& R. H. Shute (Eds.), Children helping children (pp. 21-42). New York: John Wiley \& Sons.

Whorton, D., Locke, P., Delquadri, J., \& Hall, R. V. (1989). Increasing academic skills of students with autism using fifth grade peers as tutors. Education \& Treatment of Children, 12, 38-51. 
Yasutake, D., Bryan, T., \& Dohrn, E. (1996). The effects of combining peer tutoring and attribution training on students' perceived self-competence. Remedial \& Special Education, 17(2), 83-91.

Young, C. C. (1981). Children as instructional agents for handicapped peers: A review and analysis. In P. S. Strain (Ed.), The utilization of classroom peers as behavior change agents (pp. 305-326) New York: Plenum Press.

Ysseldyke, J. E., Algozzine, B., \& Thurlow, M. L. (1992). Critical issues in special education. Boston: Houghton Mifflin.

\section{PERMISSIONS AND COPYRIGHT}

All rights are reserved. No part of this publication may be reproduced, photocopied, faxed, stored in a retrieval system, or transmitted, in any form or by any means, electronic, mechanical, recording or otherwise, without the prior written permission of the publisher.
Back issues are available for sale. Reproduction requires permission and payment of fees. It is illegal and a violation of federal copyright law to reproduce this publication without permission. Direct all inquiries to the permissions editor. 


\section{Professional update}

\section{Learning Disabilities Association of America}

February 19-22, 1997

Palmer House Hotel

Chicago, Illinois

Contact: Learning Disabilities Association of America 4156 Library Rd.

Pittsburgh, PA 15234

\section{Canadian Council for Exceptional Children}

February 26-28, 1997

Winnipeg, Manitoba

Contact: Gavin Scott

177 Oak Street

Winnipeg, MB R3M 3P7

Telephone: 204-453-46 31

\section{National Association of School Psychologists}

April 1-5, 1997

Anaheim Hilton Hotel

Anaheim, California

Contact: National Association of School Psychologists 4340 East West Highway

Suite 402

Bethesda, MD 20814

\section{International Association of Special Education}

August 3-7, 1997

Cape Town, South Africa

Contact: Helmi Owens

School of Education

Pacific Lutheran University

Tacoma, WA 98447

\section{Council for Exceptional Children}

April 9-13, 1997

Annual Conference

Salt Lake City, Utah

Contact: Council for Exceptional Children 1920 Association Drive Reston, VA 22091

\section{The China - U.S. Conference on Education}

\section{July 9-13, 1997}

Beijing, People's Republic of China

This will be the largest gathering of Chinese and American educators ever assembled. Conference cost is $\$ 2,850$ for a nineday Conference Program Package including international airfare, meals, lodging, conference fees, cultural and historic sites in Beijing. Also available are study programs to other cities, a demonstration learning center, and school partnerships. For detailed information on the Conference contact:

Global Interactions, Inc.

Department GC-97

14 West Cheryl Drive

Phoenix, AZ 85021

Telephone: 602-943-3922

Fax: 602-943-4458 